\title{
Hybrid Inhibitors of DNA Gyrase A and B: Design, Synthesis and Evaluation
}

\author{
Martina Durcik ${ }^{1}$, Žiga Skok ${ }^{1}{ }^{\circledR}$, Janez Ilaš ${ }^{1}{ }^{\circledR}$, Nace Zidar $^{1}{ }^{\circledR}$, Anamarija Zega ${ }^{1}$, Petra Éva Szili ${ }^{2}$, \\ Gábor Draskovits ${ }^{2}$, Tamás Révész ${ }^{2}$, Danijel Kikelj ${ }^{1}$, Akos Nyerges ${ }^{2,3}{ }^{10}$, Csaba Pál ${ }^{2}$, Lucija Peterlin Mašič ${ }^{1, *}$ and \\ Tihomir Tomašič ${ }^{1, * \mathbb{D}}$
}

1 University of Ljubljana, Faculty of Pharmacy, Aškerčeva cesta 7, 1000 Ljubljana, Slovenia; martina.durcik@ffa.uni-lj.si (M.D.); ziga.skok@ffa.uni-lj.si (Ž.S.); janez.ilas@ffa.uni-lj.si (J.I.); nace.zidar@ffa.uni-lj.si (N.Z.); anamarija.zega@ffa.uni-lj.si (A.Z.); danijel.kikelj@ffa.uni-lj.si (D.K.)

2 Synthetic and Systems Biology Unit, Institute of Biochemistry, Biological Research Centre, H-6726 Szeged, Hungary; szilipetraeva@gmail.com (P.É.S.); dras.gabor@gmail.com (G.D.); tamas.revesz.1@gmail.com (T.R.); nyerges.akos@brc.hu (A.N.); cpal@brc.hu (C.P.)

3 Department of Genetics, Harvard Medical School, Boston, MA 02215, USA

* Correspondence: lucija.peterlinmasic@ffa.uni-lj.si (L.P.M.); tihomir.tomasic@ffa.uni-lj.si (T.T.); Tel.: +386-1-4769-635 (L.P.M.); +386-1-4769-556 (T.T.)

check for updates

Citation: Durcik, M.; Skok, Ž.; Ilaš, J.; Zidar, N.; Zega, A.; Szili, P.É.; Draskovits, G.; Révész, T.; Kikelj, D.; Nyerges, A.; Pál, C.; et al. Hybrid Inhibitors of DNA Gyrase A and B: Design, Synthesis and Evaluation. Pharmaceutics 2021, 13, 6. https://dx.doi.org/10.3390/ pharmaceutics13010006

Received: 30 November 2020 Accepted: 19 December 2020 Published: 22 December 2020

Publisher's Note: MDPI stays neutral with regard to jurisdictional claims in published maps and institutional affiliations.

Copyright: () 2020 by the authors. Licensee MDPI, Basel, Switzerland. This article is an open access article distributed under the terms and conditions of the Creative Commons Attribution (CC BY) license (https: / / creativecommons.org/ licenses/by/4.0/).

\begin{abstract}
The discovery of multi-targeting ligands of bacterial enzymes is an important strategy to combat rapidly spreading antimicrobial resistance. Bacterial DNA gyrase and topoisomerase IV are validated targets for the development of antibiotics. They can be inhibited at their catalytic sites or at their ATP binding sites. Here we present the design of new hybrids between the catalytic inhibitor ciprofloxacin and ATP-competitive inhibitors that show low nanomolar inhibition of DNA gyrase and antibacterial activity against Gram-negative pathogens. The most potent hybrid 3a has MICs of $0.5 \mu \mathrm{g} / \mathrm{mL}$ against Klebsiella pneumoniae, $4 \mu \mathrm{g} / \mathrm{mL}$ against Enterobacter cloacae, and $2 \mu \mathrm{g} / \mathrm{mL}$ against Escherichia coli. In addition, inhibition of mutant E. coli strains shows that these hybrid inhibitors interact with both subunits of DNA gyrase (GyrA, GyrB), and that binding to both of these sites contributes to their antibacterial activity.
\end{abstract}

Keywords: antibacterial; ciprofloxacin; DNA gyrase; dual inhibitor; hybrid

\section{Introduction}

Bacterial resistance poses a major threat to global health, so new therapies against bacterial infections are urgently needed. One of the approaches to address this problem is to target multiple bacterial macromolecules [1]. Among the enzymes that enable multitargeting are the bacterial type IIA topoisomerases: DNA gyrase and topoisomerase IV. These enzymes are well-established targets for antibacterial drug discovery and they have important roles in DNA replication, transcription, repair, and recombination, through altering DNA topology during these processes [2]. They are homologous enzymes, where DNA gyrase consists of two GyrA subunits plus two GyrB subunits, and topoisomerase IV consists of two ParC subunits plus two ParE subunits, thus forming the heterotetrameric $\mathrm{A}_{2} \mathrm{~B}_{2}$ and $\mathrm{C}_{2} \mathrm{E}_{2}$ complexes, respectively. The GyrA/ParC subunits contain catalytic sites that bind to DNA, while the GyrB/ParE subunits contain ATP binding sites, and provide the energy required for the catalytic reaction through ATP hydrolysis $[3,4]$. The fluoroquinolones are catalytic site inhibitors that have been successfully used in clinical applications since the introduction of nalidixic acid, and they remain an important class of antibacterial agents for the treatment of Gram-positive and Gram-negative bacterial infections [5,6]. On the other hand, the only inhibitor of GyrB that interacts with the ATP binding site that reached the clinic was novobiocin, although therapeutic use was discontinued due to toxicity and the emergence of target-based resistance [7]. 
Mutations conferring resistance to novobiocin in Escherichia coli GyrB are most commonly found in the Arg136 residue, although other residues have also been identified where their mutation can lead to novobiocin resistance (Asp73, Gly77, Ile78, Thr165) [8]. Fluoroquinolones such as ciprofloxacin, levofloxacin, and moxifloxacin are generally effective against infections caused by Gram-positive and Gram-negative pathogens, and hence they are widely used in medicine. However, resistance to these agents has emerged and continues to spread despite recommendations to limit their use $[9,10]$. Indeed, resistance to fluoroquinolones has been detected for most bacterial infections treated with these antibiotics. In particular, the difficult to treat infections here include: (i) urinary tract infections caused by E. coli; (ii) respiratory infections caused by Streptococcus pneumoniae, which is a leading cause of community-acquired pneumonia; (iii) intra-abdominal infections caused by resistant E. coli, Salmonella spp., and Shigella; (iv) infections of the skin and skin structures through methicillin-resistant Staphylococcus aureus, where fluoroquinolones resistance is spread worldwide; and (v) gonococcal infections through Neisseria gonorrhoeae, where ciprofloxacin resistance already appeared in the late 1990s [11].

The mechanisms behind this fluoroquinolones resistance include: (i) chromosomal mutations that cause increased antibiotic efflux or reduced uptake, and hence reduced intracellular accumulation; (ii) plasmid-acquired genes that encode drug-modifying enzymes, efflux pumps, or target protection proteins; and (iii) most commonly and clinically significant, gene mutations at the target site $[5,12]$. Mutations can occur within the quinolone-resistance-determining regions of GyrA and/or ParC. The most common mutation sites in E. coli GyrA are Ser83 and Asp87, which are the key amino-acid residues for fluoroquinolone binding, and the corresponding homologous positions in $\mathrm{ParC}$, as Ser80 and Glu84 [11,13].

For these reasons, there is an urgent need for development of new drugs that circumvent common fluoroquinolone resistance mechanisms. Due to the structural similarities between DNA gyrase and topoisomerase IV, dual-targeting inhibitors can be developed that simultaneously inhibit GyrA and ParC or GyrB and ParE. The development of bacterial target-based resistance to such inhibitors will be less likely because resistance-conferring mutations would need to occur simultaneously at both targets, which is unlikely to happen $[1,7,14]$. In the present study, we used a different approach to design dual-targeting antimicrobial compounds. Specifically, we aimed to inhibit both the catalytic and the ATP binding sites of the same target protein.

In recent years, we have investigated and reported on several structural types of ATP-competitive GyrB/ParE inhibitors [15-19]. Recently, we also reported the discovery of GyrB inhibitor/ ciprofloxacin hybrids [20]. These previously designed hybrids showed weak antibacterial activities, which were shown to be mainly due to interactions with the GyrA and/or ParC subunits. To overcome this difficulty, we focused on our recently developed balanced dual GyrB/ParE ATP-competitive inhibitors 1a and 1b (Figure 1). These inhibitors have potent antibacterial activity against several Gram-positive and Gramnegative bacterial strains [21]. In this paper, we present new hybrids between ciprofloxacin and $\mathbf{1 a}$ or $\mathbf{1 b}$. By combining these molecules, we have reached superior antibacterial activities due to the interactions of these hybrids with both subunits, as GyrA and GyrB or ParC and ParE. Importantly, the compounds are effective against Gram-negative strains of bacteria that belong to the group of resistant 'ESKAPE' pathogens that pose a major threat to society and health (i.e., Enterococcus faecium, Staphylococcus aureus, Klebsiella pneumoniae, Acinetobacter baumannii, Pseudomonas aeruginosa, Enterobacter spp.) [22]. 


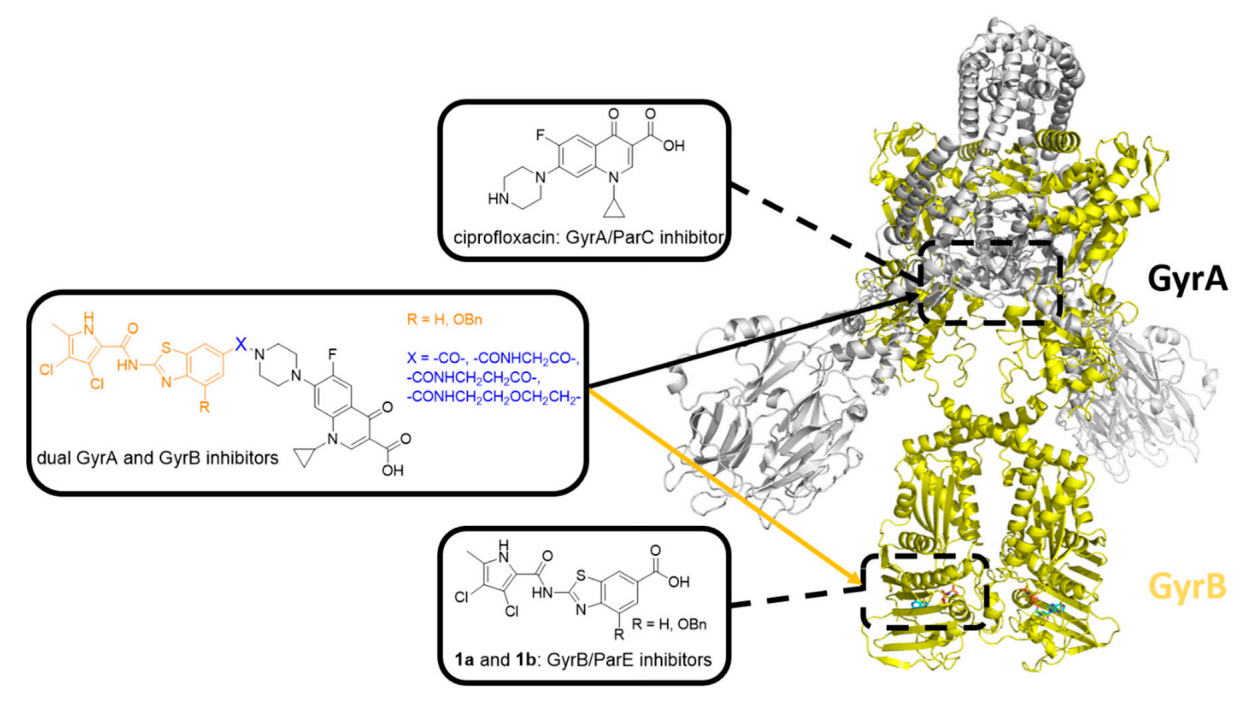

Figure 1. Structure of E. coli DNA gyrase (Protein Data Bank (PDB) entry: 6RKW [23]). The two GyrA subunits are in gray, and the binding site of GyrA/ParC inhibitor ciprofloxacin is represented by the upper black dashed rectangle. The two GyrB subunits are in yellow, and the binding site of GyrB/ParE inhibitors $\mathbf{1 a}$ and $\mathbf{1} \mathbf{b}$ is represented by the lower black dashed rectangle. The general structure of GyrA/ParC and GyrB/ParE inhibitor hybrids is shown in the middle.

\section{Materials and Methods}

\subsection{General Information-Chemistry}

Chemicals were obtained from Acros Organics (Geel, Belgium), Sigma-Aldrich (St. Louis, MO, USA), and Apollo Scientific (Stockport, UK), and were used without further purification. Analytical thin-layer chromatography was performed on silica gel plates (Merck $60 \mathrm{~F} 254 ; 0.25 \mathrm{~mm}$ ), with visualization with UV light (at $254 \mathrm{~nm}$ and $366 \mathrm{~nm}$ ) and spray reagent ninhydrin. Column chromatography was carried out on silica gel 60 (particle size, 240-400 mesh). Analytical reversed-phase HPLC analysis was performed on a liquid chromatography system (1260 Infinity II LC; Agilent Technologies Inc., Santa Clara, CA, USA). A C18 column was used $(3.5 \mu \mathrm{m}, 4.6 \mathrm{~mm} \times 150 \mathrm{~mm}$; XBridge; Waters, Milford, MA, USA), with a flow rate of $1.5 \mathrm{~mL} / \mathrm{min}$ and a sample injection volume of $10 \mu \mathrm{L}$. The mobile phase consisted of acetonitrile (solvent A) and $0.1 \%$ formic acid in $1 \%$ acetonitrile in ultrapure water (solvent B). The gradient (defined for solvent A) was: 0-1.0 $\mathrm{min}, 25 \%$; $1.0-6.0 \mathrm{~min}, 25-98 \%$; $6.0-6.5 \mathrm{~min}, 98 \%$; $6.5-7.5 \mathrm{~min}, 98-25 \%$; $7.5-10.5 \mathrm{~min}, 25 \%$. Ultrapure water was obtained with a Milli-Q Advantage A10 water purification system (Millipore, Merck, Burlington, MA, USA). Melting points were determined on a hot stage microscope (Reichert) and are uncorrected. ${ }^{1} \mathrm{H}$ NMR spectra were recorded at $400 \mathrm{MHz}$ (Bruker AVANCE III 400 spectrometer; Bruker Corporation, Billerica, MA, USA) in DMSO$d_{6}$ solutions, with tetramethylsilane as the internal standard. Infrared (IR) spectra were recorded (Thermo Nicolet Nexus 470 ESP FT-IR spectrometer; Thermo Fisher Scientific, Waltham, MA, USA). Mass spectra were obtained using a compact mass spectrometer (Advion expression; Advion Inc., Ithaca, NY, USA). High-resolution mass spectrometry was also performed (Exactive Plus Orbitrap; Thermo Fisher Scientific, Waltham, MA, USA). Detailed synthetic procedures and analytical data for all of the compounds are in Appendix A. ${ }^{1} \mathrm{H}$ NMR spectra and HPLC chromatograms can be found in Supplementary Materials.

\subsection{Molecular Docking}

Molecular docking calculations were performed using Schrödinger Release 2020-1 (Schrödinger, LLC, New York, NY, USA, 2020). The crystal structures of S. aureus DNA gyrase A in complex with moxifloxacin (PDB entry: 5CDQ [24]) and S. aureus DNA gyrase $\mathrm{B}$ in complex with $\mathbf{1 b}$ (PDB entry: 6TCK [21]) were retrieved from the Protein Data Bank. The proteins were prepared using Protein Preparation Wizard, with the default settings. 
The receptor grid was calculated for the ligand-binding site, and the designed hybrids were docked using the Glide XP protocol, as implemented in Schrödinger Release 2020-1 (Glide, Schrödinger, LLC, New York, NY, USA, 2020). Figures were prepared with PyMOL [25].

\subsection{Determination of Inhibitory Activities on Escherichia coli DNA Gyrase and Topoisomerase IV}

The assay for determination of the $\mathrm{IC}_{50}$ values was performed according to previously reported procedures [26].

Briefly, inhibitory activities were determined using supercoiling (for DNA gyrase) and relaxation (for topoisomerase IV) assay kits (Inspiralis, Norwich, UK) on streptavidincoated 96-well microtiter plates from Thermo Scientific Pierce (Thermo Fisher Scientific, Waltham, MA, USA). First, the plates were rehydrated with Wash Buffer and the biotinylated oligonucleotide TFO1 was then immobilized. After washing off the unbound oligonucleotide with Wash Buffer, the enzyme assay was performed. Into each well was added $24 \mu \mathrm{L}$ of mixture containing $6 \mu \mathrm{L}$ of Assay Buffer (containing ATP), $0.75 \mu \mathrm{L}$ of relaxed (for E. coli DNA gyrase supercoiling assay) or supercoiled (for E. coli topoisomerase IV relaxation assay) pNO1 plasmid and $17.25 \mu \mathrm{L}$ of water. Additionally, $3 \mu \mathrm{L}$ of a solution of the inhibitor in 10\% DMSO containing $0.008 \%$ Tween 20 and $3 \mu \mathrm{L}$ of enzyme $(1.5 \mathrm{U})$ in Dilution Buffer were also added to the wells. Reaction solutions were incubated at $37^{\circ} \mathrm{C}$ for $30 \mathrm{~min}$. The TF buffer was added to terminate the enzymatic reaction and after additional incubation for $30 \mathrm{~min}$ at room temperature, which allowed for triplex formation (biotin-oligonucleotide-plasmid), the unbound plasmid was washed off using TF buffer. Promega Diamond dye in T10 buffer was then added. After another 15 min incubation at room temperature in the dark, the fluorescence (excitation: $485 \mathrm{~nm}$, emission: $535 \mathrm{~nm}$ ) was measured with an automated microplate reader $\left(\right.$ Synergy $^{\mathrm{TM}} \mathrm{H} 4$, BioTek, Winooski, VT, USA). Initial screening was done at $10 \mu \mathrm{M}$ and $1 \mu \mathrm{M}$ concentrations of inhibitors and for the active inhibitors at these concentrations, $\mathrm{IC}_{50}$ values were determined using seven concentrations of tested compounds. The test concentration range in E. coli DNA gyrase assay was $0.028-10 \mu \mathrm{M}$ for compounds $\mathbf{3 a}$ and $\mathbf{3 b}, 0.0028-1 \mu \mathrm{M}$ for $\mathbf{7 a}, \mathbf{7} \mathbf{b}$, and $\mathbf{1 1} \mathbf{a}$, and $0.0011-$ 0.4 for $\mathbf{1 1 b}$. Compounds were diluted using 0.375 -fold serial dilution steps of the given compound. The test concentration range in E. coli topoisomerase IV assay was $0.063-4 \mu \mathrm{M}$ for compound $\mathbf{3 a}$ and $0.156-10 \mu \mathrm{M}$ for compounds $\mathbf{7 a}, \mathbf{7 b}$, and $\mathbf{1 1 b}$. Here, the compounds were diluted using 2-fold serial dilution steps of the given compound. GraphPad Prism 6.0 software was used to calculate the $\mathrm{IC}_{50}$ values, which were determined in at least two independent measurements, and their means are given as the final result. Novobiocin was used as the positive control. Dose-response curves can be found in Supplementary Materials.

\subsection{Determination of Antibacterial Activities}

The following clinical microbiology control strains were obtained from American Type Culture Collection (ATCC) via Microbiologics Inc. (St. Cloud, MN, USA): A. baumannii (ATCC 17978); E. coli (ATCC 25922); K. pneumoniae (ATCC 10031); P. aeruginosa (ATCC 27853); and Enterobacter cloacae spp. cloacae (ATCC 13047). E. coli MG1655 originated from the laboratory collection of Dr. Csaba Pál. The GyrA and GyrB mutant strains of E. coli MG1655 were constructed using pORTMAGE [27] recombineering (Addgene plasmid \#120418; http: / / n2t.net/addgene:120418; RRID:Addgene_120418), according to the published protocol [28]. E. coli K-12 BW25113 single-gene knockout mutant lines $\Delta$ dapF, $\Delta \mathrm{mrcB}, \Delta$ surA,$\Delta \mathrm{acrB}$ and $\Delta$ tolC originated form the Keio collection copy owned by the laboratory of Dr. Csaba Pál [29].

Cation-adjusted Mueller Hinton II broth (MHBII) was used for growth of the bacteria under standard laboratory conditions, for antimicrobial susceptibility tests, and for selection of resistant variants. To prepare the MHBII broth, $22 \mathrm{~g}$ MHBII powder (containing $3 \mathrm{~g}$ beef extract, $17.5 \mathrm{~g}$ acid hydrolysate of casein, $1.5 \mathrm{~g}$ starch; Becton, Dickinson and Co., Franklin Lakes, NJ, USA) was dissolved in $1 \mathrm{~L}$ water. MHBII agar was prepared by addition of $14 \mathrm{~g}$ agar (Bacto; Molar Chemicals, Halásztelek, Hungary) to 1 L broth. 
Minimum inhibitory concentrations (MICs) were determined using a standard serial broth microdilution technique, according to the Clinical and Laboratory Standards Institute guidelines [30]. Bacterial strains were inoculated onto MHBII agar plates and grown overnight at $37^{\circ} \mathrm{C}$. Next, three individual colonies from each strain were inoculated into $1 \mathrm{~mL}$ MHBII medium and propagated at $37{ }^{\circ} \mathrm{C}$ overnight, with agitation at $250 \mathrm{rpm}$. For Enterococcus sp., the cells were plated in BHI agar plates, and BHI broth was used to determine the MICs. To perform the MIC assays, 12-step serial dilutions using two-fold dilution steps of the given compound (each dissolved in 100\% DMSO) were generated in 96-well microtiter plates (Corning Inc., Corning, NY, USA). The concentrations used were: $64,32,16,8,4,2,1,0.5,0.25,0.125,0.0625$, and $0.03125 \mu \mathrm{g} / \mathrm{mL}$. Following the dilutions, each well was seeded with $5 \times 10^{4}$ bacterial cells. Each measurement was performed in three parallel replicates, and to avoid possible edge effects in the microwell plates, the outside rows $(\mathrm{A}, \mathrm{H})$ were filled with sterile medium. Following the inoculations, the plates were covered with the lids and wrapped in polyethylene plastic bags, to minimize evaporation but to allow $\mathrm{O}_{2}$ transfer. The plates were incubated at $37^{\circ} \mathrm{C}$ under continuous shaking at $150 \mathrm{rpm}$ for $18 \mathrm{~h}$. After incubation, the $\mathrm{OD}_{600}$ of each well was measured using a microplate reader (Synergy 2; Biotek, Winooski, VT, USA). The MICs were defined as the antibiotic concentrations which inhibited the growth of the bacterial cultures; i.e., the drug concentration where the average $\mathrm{OD}_{600}$ increment of the three technical replicates was below 1.5-fold the background OD increment.

\section{Results and Discussion}

\subsection{Design}

Our first series of dual GyrA and GyrB inhibitor hybrids was designed by combining the GyrA inhibitor ciprofloxacin with benzothiazole-based GyrB inhibitors [20]. Although the GyrB inhibitors used in the first series of hybrids showed potent DNA gyrase inhibition, they showed only low antibacterial activity [17]. When the hybrids were tested against bacteria, we showed that in the bacteria they only bound to GyrA, and not to GyrB, which means that the observed antibacterial activity was mainly due to the ciprofloxacin part that interacted with GyrA. In the present series, we combined our balanced dualtargeting GyrB and ParE inhibitors $\mathbf{1 a}$ and $\mathbf{1 b}$ with potent antibacterial activity against Gram-positive and Gram-negative strains with ciprofloxacin [21]. The new hybrids were prepared either by direct fusion of inhibitors $\mathbf{1 a}$ and $\mathbf{1} \mathbf{b}$ with ciprofloxacin, or by linking the two molecules with linkers of different lengths (i.e., glycine in $7 \mathbf{a}, \beta$-alanine in $7 \mathbf{b}$ or 2-ethoxyethyl in 11a and 11b). The design of the new dual GyrA and GyrB inhibitors is shown in Figures 1 and 2.

Molecular docking showed that all designed hybrids $\mathbf{3 a}, \mathbf{3 b}, \mathbf{7} \mathbf{a}, \mathbf{7 b}, \mathbf{1 1} \mathbf{a}$ and $\mathbf{1 1} \mathbf{b}$ can bind to either GyrA or GyrB. As an example, the docking binding mode of a representative hybrid 3a in GyrA and GyrB active sites is presented in Figure 2. Docking of 3a to the catalytic site of GyrA reproduced the binding conformation of the fluoroquinolone portion, as observed for moxifloxacin in the crystal structure. Important hydrogen bonds were formed with Ser84, Arg122 and a magnesium ion, while $\pi$-stacking interactions were formed with DNA bases. The GyrB part of hybrid 3a made additional hydrophobic contacts with Asn474-476 (Figure 2). At the ATP binding site of GyrB, the pyrrolamide moiety of 3a interacted with Asp81 and a structural water molecule, as observed for $\mathbf{1 b}$ in the crystal structure. The carbonyl group connecting the benzothiazole moiety to the piperidine nitrogen atom of ciprofloxacin formed a hydrogen bond with Arg144. Furthermore, the ciprofloxacin part of 3a pointed towards the bulk solvent and did not interfere with the binding (Figure 2). Similar binding modes were obtained also for other designed GyrA/GyrB inhibitor hybrids. 


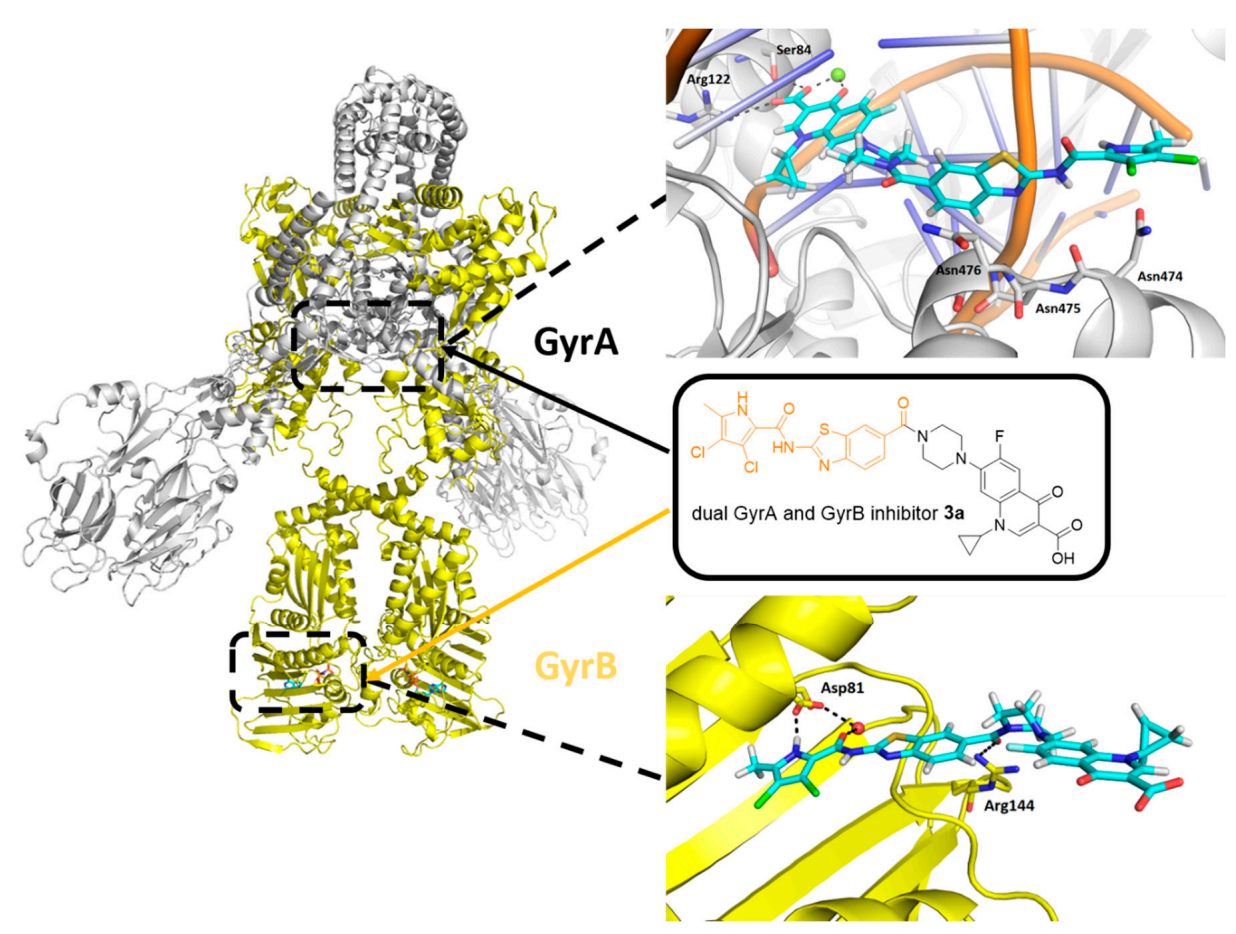

Figure 2. Docking binding modes of the representative hybrid 3a (cyan sticks) in the catalytic site of GyrA (S. aureus GyrA in gray; DNA in orange; PDB entry: 5CDQ [24]) and in the ATP-binding site of GyrB (S. aureus GyrB in yellow; PDB entry: 6TCK [21]). For clarity, only amino-acid residues forming hydrogen bonds (dashed lines) are presented as sticks. The magnesium ion in GyrA is a green sphere, while the structural water in GyrB is a red sphere.

\subsection{Chemistry}

The fused hybrids $\mathbf{3} \mathbf{a}$ and $\mathbf{3 b}$ were prepared in the one-step synthesis presented in Scheme 1. Compounds $\mathbf{1 a}$ and $\mathbf{1} \mathbf{b}$ [21] were coupled to ciprofloxacin (2) using the reagents 1ethyl-3-(3-dimethylaminopropyl)carbodiimide (EDC) and 1-hydroxybenzotriazole (HOBt), to obtain the final compounds $\mathbf{3} \mathbf{a}$ and $\mathbf{3 b}$.

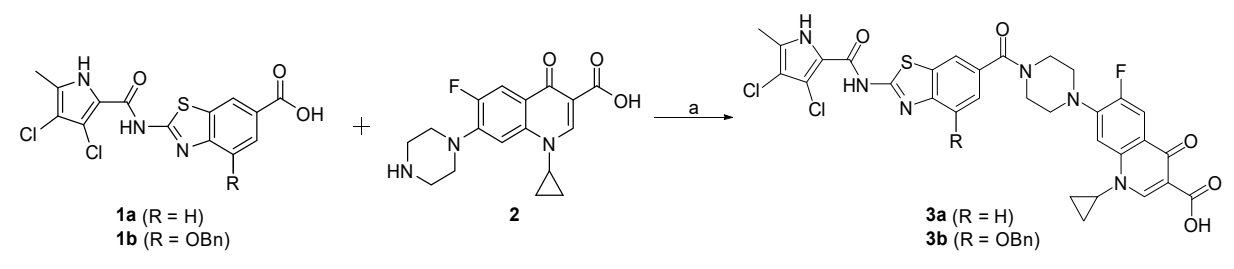

Scheme 1. Reagents and conditions: (a) 1-ethyl-3-(3-dimethylaminopropyl)carbodiimide (EDC), 1-hydroxybenzotriazole (HOBt), $\mathrm{N}$-methylmorpholine (NMM), $\mathrm{N}, \mathrm{N}$-dimethylformamide (DMF), rt, $15 \mathrm{~h}$.

The synthesis of the linked compounds $7 \mathbf{a}$ and $7 \mathbf{b}$ is shown in Scheme 2 . First, ciprofloxacin (2) was coupled to $N$-(tert-butoxycarbonyl)glycine (4a) or 3-(N-(tertbutoxycarbonyl)amino)propanoic acid (4b) using EDC- and HOBt-promoted coupling, to obtain compounds $\mathbf{5 a}$ and $\mathbf{5 b}$. The Boc protecting groups of $\mathbf{5 a}$ and $\mathbf{5 b}$ were removed by acidolysis, and the obtained intermediates $\mathbf{6 a}$ and $\mathbf{6 b}$ were coupled to $1 \mathrm{a}$ to obtain the desired compounds $7 \mathbf{a}$ and $7 \mathbf{b}$. 


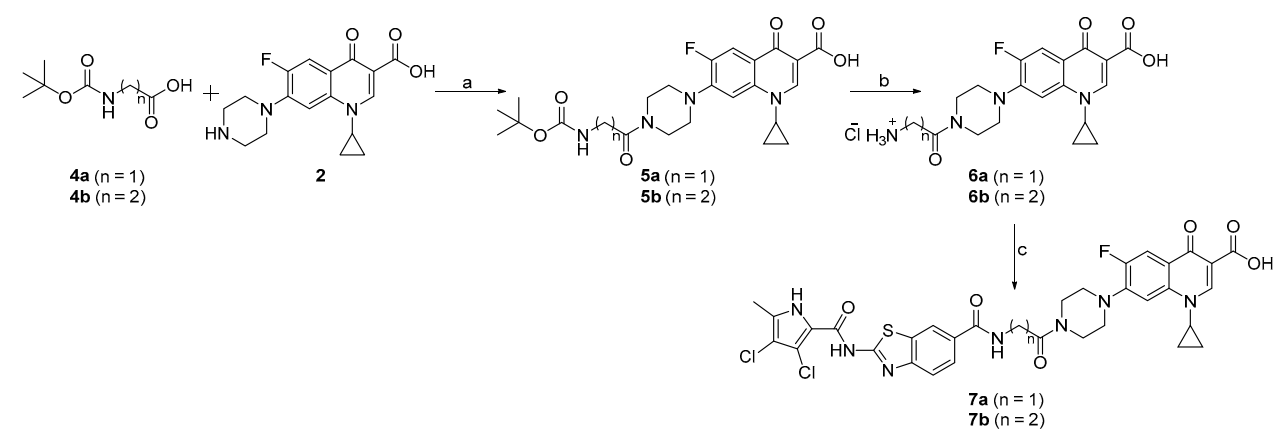

Scheme 2. Reagents and conditions: (a) EDC, HOBt, NMM, DMF, rt, 15 h; (b) $4 \mathrm{M} \mathrm{HCl}$ in 1,4-dioxane, 1,4-dioxane, rt, 3 h; (c) 1a, EDC, HOBt, NMM, DMF, rt, 15 h.

The compounds $\mathbf{1 1 a}$ and $\mathbf{1 1} \mathbf{b}$ were synthesized according to Scheme 3 . The reaction between 2-(2-((tert-butoxycarbonyl)amino)ethoxy)ethyl methanesulfonate (8) and ciprofloxacin (2) using triethylamine $\left(\mathrm{Et}_{3} \mathrm{~N}\right)$ in DMF and water yielded intermediate 9. The Boc protecting group of 9 was removed with $\mathrm{HCl}$ in 1,4-dioxane to obtain compound $\mathbf{1 0}$. In the final step, compound $\mathbf{1 0}$ was coupled to $\mathbf{1 a}$ or $\mathbf{1} \mathbf{b}$, to obtain the final compounds 11a and 11b.

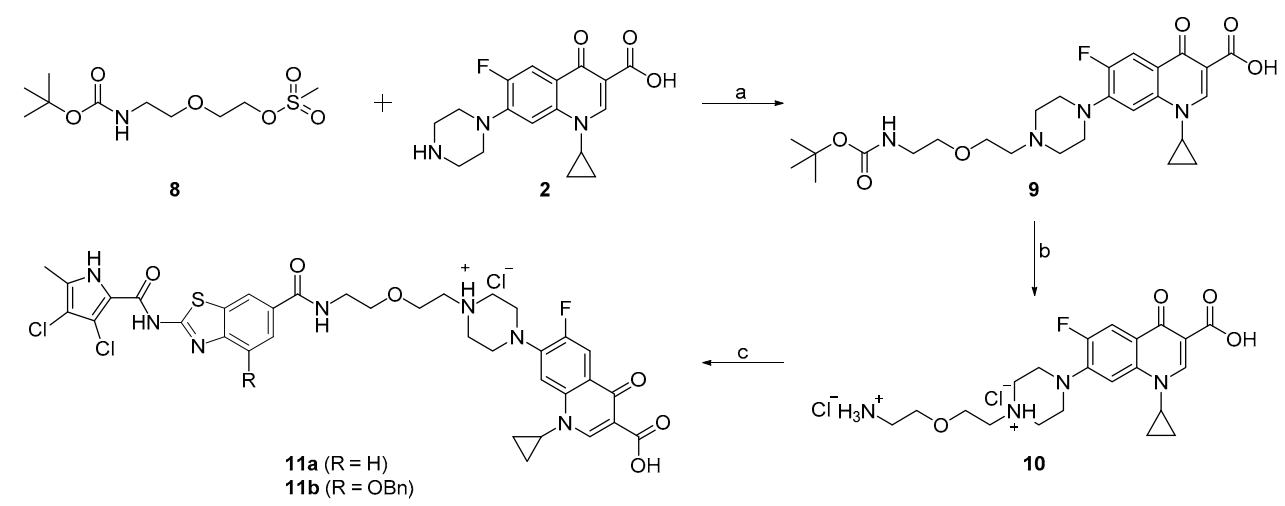

Scheme 3. Reagents and conditions: (a) $\mathrm{Et}_{3} \mathrm{~N}, \mathrm{DMF} / \mathrm{H}_{2} \mathrm{O}, 80^{\circ} \mathrm{C}, 72 \mathrm{~h}$; (b) $4 \mathrm{M} \mathrm{HCl}$ in 1,4-dioxane, 1,4-dioxane, rt, 3 h; (c) 1a or 1b, EDC, HOBt, NMM, DMF, rt, 15 h.

\subsection{Enzyme Inhibition and Antibacterial Activities}

Six new hybrids were prepared and tested for their inhibitory activities against DNA gyrase and topoisomerase IV from E. coli in supercoiling and relaxation assays, respectively (Table 1). The antibacterial activities of the hybrids were tested against Gram-negative bacteria from the ESKAPE group of pathogens, and are shown in Table 2. 
Table 1. Inhibitory activities of the new hybrid compounds against E. coli DNA gyrase and topoisomerase IV.

\begin{tabular}{|c|c|c|}
\hline \multirow{3}{*}{ Cpd. } & \multirow{3}{*}{$\mathbf{R}$} & \multirow{2}{*}{$\frac{\mathrm{IC}_{50}[\mathrm{nM}]^{1}}{E . \text { coli }^{1}}$} \\
\hline & & \\
\hline & & $\begin{array}{c}\text { Topoisomerase } \\
\text { IV }\end{array}$ \\
\hline $3 a$ & $\mathrm{H}$ & $1000 \pm 150$ \\
\hline $3 b$ & OBn & $>10,000$ \\
\hline $7 a$ & $\mathrm{H}$ & $2500 \pm 1300$ \\
\hline $7 \mathrm{~b}$ & $\mathrm{H}$ & $3100 \pm 0$ \\
\hline $11 a^{2}$ & $\mathrm{H}$ & $>10,000$ \\
\hline $11 b^{3}$ & OBn & $2500 \pm 1100$ \\
\hline & $1 a^{4}$ & $500 \pm 280$ \\
\hline & $\mathbf{1} \mathbf{b}^{5}$ & $350 \pm 50$ \\
\hline & $\mathrm{CP}^{6}$ & $5400 \pm 2100$ \\
\hline & $\mathrm{NB}^{7}$ & $11,000 \pm 2000$ \\
\hline
\end{tabular}

\footnotetext{
1 Concentration of compound (mean \pm SD, in $n M$ ) that inhibits the enzyme activity by $50 \%$; $2,{ }^{3}$ Compounds 11a and $\mathbf{1 1} \mathbf{b}$ were obtained as hydrochloride salts; ${ }^{4},{ }^{5} \mathbf{1 a}$ and $\mathbf{1 b}$, GyrB and ParE inhibitors; ${ }^{6} \mathrm{CP}$, ciprofloxacin; ${ }^{7} \mathrm{NB}$, novobiocin.
}

Table 2. Minimum inhibitory concentration (MIC) values of the new hybrid compounds against the indicated Gram-negative bacterial strains.

\begin{tabular}{|c|c|c|c|c|c|}
\hline \multirow[b]{2}{*}{ Cpd. } & \multicolumn{5}{|c|}{$\operatorname{MIC}[\mu \mathrm{g} / \mathrm{mL}]^{1}$} \\
\hline & $\begin{array}{c}\text { A. } \\
\text { baumannii } \\
\text { ATCC } 17978\end{array}$ & $\begin{array}{c}\text { P. aeruginosa } \\
\text { ATCC } 27863\end{array}$ & $\begin{array}{c}\text { K. } \\
\text { pneumoniae } \\
\text { ATCC } 10031\end{array}$ & $\begin{array}{l}\text { E. cloacae } \\
\text { spp. cloacae } \\
\text { ATCC } 13047\end{array}$ & $\begin{array}{c}\text { E. coli } \text { ATCC } \\
25922\end{array}$ \\
\hline $3 a$ & $\begin{array}{c}16 \\
(23.4 \mu \mathrm{M})\end{array}$ & $\begin{array}{c}64 \\
(93.6 \mu \mathrm{M})\end{array}$ & $\begin{array}{c}0.5 \\
(0.73 \mu \mathrm{M})\end{array}$ & $\begin{array}{c}4 \\
(5.85 \mu \mathrm{M})\end{array}$ & $\begin{array}{c}2 \\
(2.93 \mu \mathrm{M})\end{array}$ \\
\hline $3 b$ & $\begin{array}{c}>64 \\
(>81.0 \mu \mathrm{M})\end{array}$ & $\begin{array}{c}>64 \\
(>81.0 \mu \mathrm{M})\end{array}$ & $\begin{array}{c}>64 \\
(>81.0 \mu \mathrm{M})\end{array}$ & $\begin{array}{c}>64 \\
(>81.0 \mu \mathrm{M})\end{array}$ & $\begin{array}{c}>64 \\
(>81.0 \mu \mathrm{M})\end{array}$ \\
\hline $7 a$ & $\begin{array}{c}>64 \\
(>86.4 \mu \mathrm{M})\end{array}$ & $\begin{array}{c}>64 \\
(>86.4 \mu \mathrm{M})\end{array}$ & $\begin{array}{c}4 \\
(5.40 \mu \mathrm{M})\end{array}$ & $\begin{array}{c}>64 \\
(>86.4 \mu \mathrm{M})\end{array}$ & $\begin{array}{c}>64 \\
(>86.4 \mu \mathrm{M})\end{array}$ \\
\hline $7 \mathrm{~b}$ & $\begin{array}{c}>64 \\
(>84.8 \mu \mathrm{M})\end{array}$ & $\begin{array}{c}>64 \\
(>84.8 \mu \mathrm{M})\end{array}$ & $\begin{array}{c}8 \\
(10.6 \mu \mathrm{M})\end{array}$ & $\begin{array}{c}>64 \\
(>84.8 \mu \mathrm{M})\end{array}$ & $\begin{array}{c}>64 \\
(>84.8 \mu \mathrm{M})\end{array}$ \\
\hline $11 \mathrm{a}$ & $\begin{array}{c}>64 \\
(>82.9 \mu \mathrm{M})\end{array}$ & $\begin{array}{c}>64 \\
(>82.9 \mu \mathrm{M})\end{array}$ & $\begin{array}{c}4 \\
(5.18 \mu \mathrm{M})\end{array}$ & $\begin{array}{c}64 \\
(82.9 \mu \mathrm{M})\end{array}$ & $\begin{array}{c}32 \\
(41.5 \mu \mathrm{M})\end{array}$ \\
\hline $11 b$ & $\begin{array}{c}64 \\
(72.9 \mu \mathrm{M})\end{array}$ & $\begin{array}{c}>64 \\
(>72.9 \mu \mathrm{M})\end{array}$ & $\begin{array}{c}1 \\
(1.14 \mu \mathrm{M})\end{array}$ & $\begin{array}{c}16 \\
(18.2 \mu \mathrm{M})\end{array}$ & $\begin{array}{c}4 \\
(4.56 \mu \mathrm{M})\end{array}$ \\
\hline $1 a^{2}$ & $\begin{array}{c}4 \\
(10.8 \mu \mathrm{M})\end{array}$ & $\begin{array}{c}8 \\
(21.6 \mu \mathrm{M})\end{array}$ & $\begin{array}{c}1 \\
(2.70 \mu \mathrm{M})\end{array}$ & $\begin{array}{c}>64 \\
(>173 \mu \mathrm{M})\end{array}$ & $\begin{array}{c}4 \\
(10.8 \mu \mathrm{M})\end{array}$ \\
\hline $1 b^{3}$ & $\begin{array}{c}2 \\
(4.20 \mu \mathrm{M})\end{array}$ & $\begin{array}{c}2 \\
(4.20 \mu \mathrm{M})\end{array}$ & $\begin{array}{c}4 \\
(8.40 \mu \mathrm{M})\end{array}$ & $\begin{array}{c}>64 \\
(>134 \mu \mathrm{M})\end{array}$ & $\begin{array}{c}16 \\
(33.6 \mu \mathrm{M})\end{array}$ \\
\hline $\mathrm{CP}^{4}$ & $\begin{array}{c}0.25 \\
(0.75 \mu \mathrm{M})\end{array}$ & $\begin{array}{c}0.25 \\
(0.75 \mu \mathrm{M})\end{array}$ & $\begin{array}{c}<0.03125 \\
(<0.0943 \mu \mathrm{M})\end{array}$ & $\begin{array}{c}<0.03125 \\
(<0.0943 \mu \mathrm{M})\end{array}$ & $\begin{array}{c}<0.03125 \\
(<0.0943 \mu \mathrm{M})\end{array}$ \\
\hline
\end{tabular}

${ }^{1} \mathrm{MIC}$, minimum inhibitory concentration; ${ }^{2},{ }^{3} \mathbf{1 a}$ and $\mathbf{1 b}$, GyrB and ParE inhibitors; ${ }^{4} \mathrm{CP}$, ciprofloxacin. Measurements were performed according to the Clinical and Laboratory Standards Institute guidelines, with three independent measurements. 
Four hybrids $(\mathbf{7 a}, \mathbf{7 b}, \mathbf{1 1} \mathbf{a}, \mathbf{1 1 b})$ showed potent nanomolar inhibitory activities against DNA gyrase from E. coli ( $\mathrm{IC}_{50}$ range, 14-130 nM; Table 1), which were comparable or superior to the activity of the GyrA inhibitor ciprofloxacin ( $\mathrm{IC}_{50}, 120 \mathrm{nM}$; Table 1). Compared to the GyrB inhibitors 1a and $\mathbf{1 b}$, the hybrids showed weaker inhibition, with the exception of $\mathbf{1 1} \mathbf{b}$, which showed very promising activity, with an $\mathrm{IC}_{50}$ of $14 \mathrm{nM}$. Inhibition of topoisomerase IV was weaker for all of these tested compounds, with low micromolar activities for $\mathbf{3 a}, \mathbf{7 a}, \mathbf{7 b}$, and $\mathbf{1 1} \mathbf{b}$, and lack of activity for $\mathbf{3 b}$ and $\mathbf{1 1 a}$. Ciprofloxacin also inhibited topoisomerase IV in the low micromolar range, with an $\mathrm{IC}_{50}$ of $5.4 \mu \mathrm{M}$. These data demonstrate that the addition of these linkers that give flexibility to the molecules was beneficial for the inhibitory activities: here, the fused molecules $\mathbf{3 a}$ and $\mathbf{3 b}$ showed weaker inhibition of DNA gyrase compared to the linked molecules $7 \mathbf{a}, \mathbf{7 b}, \mathbf{1 1 a}$, and 11b. On the contrary, the best antibacterial activity was obtained for the fused hybrid 3a. Compound 3a showed potent MICs against K. pneumoniae $(0.5 \mu \mathrm{g} / \mathrm{mL})$, E. cloacae $(4 \mu \mathrm{g} / \mathrm{mL})$, and E. coli $(2 \mu \mathrm{g} / \mathrm{mL}$ ) (Table 2). Compared to the other five hybrids, $\mathbf{3 a}$ is the smallest molecule, so one hypothesis for its superior activity is that this size difference contributes to better cellular uptake. However, because of experiments detailed below we came to doubt that differences in cellular uptake account for its superior activity. Compounds $7 \mathbf{a}$ and $\mathbf{7 b}$, with the glycine and $\beta$-alanine linkers, showed no significant antibacterial activities, except against K. pneumoniae, while the ether compounds $\mathbf{1 1 a}$ and $\mathbf{1 1 b}$ were active against $E$. coli in addition to K. pneumoniae (Table 2). The activities of $\mathbf{1 1 a}$ and $\mathbf{1 1} \mathbf{b}$ against these two bacterial strains were comparable to the GyrB inhibitors $\mathbf{1 a}$ and $\mathbf{1 b}$, while they were lower than the antibacterial activity of ciprofloxacin. In addition, the dual-targeting ligands $\mathbf{3 a}$ and $\mathbf{1 1 b}$ showed promising antibacterial activities also against $E$. cloacae (MICs, 4, $16 \mu \mathrm{g} / \mathrm{mL}$, respectively), against which the GyrB inhibitors $\mathbf{1 a}$ and $\mathbf{1 b}$ were inactive. Compound $\mathbf{3 b}$ showed only weak micromolar enzyme inhibition, and was therefore almost inactive against all of these bacterial strains.

To study the factors that influence the antibacterial activities of these compounds, the hybrids were also tested on E. coli BW25113 wild-type and mutant strains (Table 3). The first three of the mutated genes for $\operatorname{dap} F, \operatorname{mrcB}$, and $\operatorname{sur} A$ are involved in peptidoglycan biosynthesis and maturation of outer membrane proteins [31]; this leads to mutants with disturbed cell walls, which are thus more permeable. The other two mutants were for the $a c r B$ and tol $C$ genes that encode efflux pump proteins [32]. When the hybrids were tested against the $\triangle d a p F, \Delta m r c B$, and $\triangle s u r A$ mutants with impaired cell walls, there were no differences in the activities compared to the wild-type strain. Therefore, poor penetration does not appear to be the main reason for the weak activities of these GyrA/GyrB inhibitor hybrids. In contrast, when tested against the $\Delta$ tolC mutant with an impaired efflux pump, the activities were improved for all of these tested hybrids. For $\mathbf{3 a}$ and $\mathbf{1 1 b}$, the MICs showed changes of 4 -fold or 8 -fold, while for $7 \mathbf{a}, 7 \mathbf{b}$, and $\mathbf{1 1 a}$ the changes were above 32-fold or 64-fold. From these data, we can conclude that the hybrids $7 \mathbf{a}, 7 \mathbf{b}$, and 11a underwent strong efflux from the bacterial cell, which might be the reason for their weak activity or inactivity against the wild-type strains (Table 2). Although $\mathbf{3 a}$ and $\mathbf{1 1 b}$ also showed improved activities here, the MIC changes were not as pronounced, and their good activities on the wild-type strain show that the efflux was not detrimental to their antibacterial activities. 
Table 3. Minimum inhibitory concentrations of these new hybrid compounds against $E$. coli BW25113 wild-type and mutant strains with impaired cell-wall structure $(\triangle d a p F, \Delta m r c B, \Delta s u r A)$ and efflux pumps $(\triangle a c r B, \Delta t o l C)$.

\begin{tabular}{|c|c|c|c|c|c|c|}
\hline \multirow[b]{2}{*}{ Cpd. } & \multicolumn{6}{|c|}{ Minimum Inhibitory Concentration $[\mu \mathrm{g} / \mathrm{mL}]$} \\
\hline & $\begin{array}{c}\text { E. coli } \\
\text { BW25113 } \\
\text { WT }^{1}\end{array}$ & $\begin{array}{c}\text { E. coli } \\
\text { BW25113 } \\
\Delta \text { dapF }\end{array}$ & $\begin{array}{c}\text { E. coli } \\
\text { BW25113 } \\
\Delta m r c B\end{array}$ & $\begin{array}{c}\text { E. coli } \\
\text { BW25113 } \\
\Delta s u r A\end{array}$ & $\begin{array}{c}\text { E. coli } \\
\text { BW25113 } \\
\Delta a c r B\end{array}$ & $\begin{array}{c}\text { E. coli } \\
\text { BW25113 } \\
\Delta \text { tolC }\end{array}$ \\
\hline $3 a$ & $\begin{array}{c}4 \\
(5.85 \mu \mathrm{M})\end{array}$ & $\begin{array}{c}4 \\
(5.85 \mu \mathrm{M})\end{array}$ & $\begin{array}{c}4 \\
(5.85 \mu \mathrm{M})\end{array}$ & $\begin{array}{c}4 \\
(5.85 \mu \mathrm{M})\end{array}$ & $\begin{array}{c}4 \\
(5.85 \mu \mathrm{M})\end{array}$ & $\begin{array}{c}1 \\
(1.46 \mu \mathrm{M})\end{array}$ \\
\hline $3 b$ & $\begin{array}{c}>64 \\
(>81.0 \mu \mathrm{M})\end{array}$ & $\begin{array}{c}>64 \\
(>81.0 \mu \mathrm{M})\end{array}$ & $\begin{array}{c}>64 \\
(>81.0 \mu \mathrm{M})\end{array}$ & $\begin{array}{c}>64 \\
(>81.0 \mu \mathrm{M})\end{array}$ & $\begin{array}{c}>64 \\
(>81.0 \mu \mathrm{M})\end{array}$ & $\begin{array}{c}16 \\
(20.3 \mu \mathrm{M})\end{array}$ \\
\hline $7 a$ & $\begin{array}{c}>64 \\
(>86.4 \mu \mathrm{M})\end{array}$ & $\begin{array}{c}>64 \\
(>86.4 \mu \mathrm{M})\end{array}$ & $\begin{array}{c}>64 \\
(>86.4 \mu \mathrm{M})\end{array}$ & $\begin{array}{c}>64 \\
(>86.4 \mu \mathrm{M})\end{array}$ & $\begin{array}{c}>64 \\
(>86.4 \mu \mathrm{M})\end{array}$ & $\begin{array}{c}2 \\
(2.70 \mu \mathrm{M})\end{array}$ \\
\hline $7 \mathbf{b}$ & $\begin{array}{c}>64 \\
(>84.8 \mu \mathrm{M})\end{array}$ & $\begin{array}{c}>64 \\
(>84.8 \mu \mathrm{M})\end{array}$ & $\begin{array}{c}>64 \\
(>84.8 \mu \mathrm{M})\end{array}$ & $\begin{array}{c}>64 \\
(>84.8 \mu \mathrm{M})\end{array}$ & $\begin{array}{c}>64 \\
(>84.8 \mu \mathrm{M})\end{array}$ & $\begin{array}{c}2 \\
(2.65 \mu \mathrm{M})\end{array}$ \\
\hline $11 \mathrm{a}$ & $\begin{array}{c}32 \\
(41.5 \mu \mathrm{M})\end{array}$ & $\begin{array}{c}32 \\
(41.5 \mu \mathrm{M})\end{array}$ & $\begin{array}{c}32 \\
(41.5 \mu \mathrm{M})\end{array}$ & $\begin{array}{c}16 \\
(20.7 \mu \mathrm{M})\end{array}$ & $\begin{array}{c}32 \\
(41.5 \mu \mathrm{M})\end{array}$ & $\begin{array}{c}0.5 \\
(0.65 \mu \mathrm{M})\end{array}$ \\
\hline $11 b$ & $\begin{array}{c}8 \\
(9.11 \mu \mathrm{M})\end{array}$ & $\begin{array}{c}8 \\
(9.11 \mu \mathrm{M})\end{array}$ & $\begin{array}{c}8 \\
(9.11 \mu \mathrm{M})\end{array}$ & $\begin{array}{c}8 \\
(9.11 \mu \mathrm{M})\end{array}$ & $\begin{array}{c}8 \\
(9.11 \mu \mathrm{M})\end{array}$ & $\begin{array}{c}1 \\
(1.14 \mu \mathrm{M})\end{array}$ \\
\hline $\mathrm{CP}^{2}$ & $\begin{array}{c}<0.03125 \\
(<0.0943 \\
\mu \mathrm{M})\end{array}$ & $\begin{array}{c}<0.03125 \\
(<0.0943 \\
\mu \mathrm{M})\end{array}$ & $\begin{array}{c}<0.03125 \\
(<0.0943 \\
\mu \mathrm{M})\end{array}$ & $\begin{array}{c}<0.03125 \\
(<0.0943 \\
\mu \mathrm{M})\end{array}$ & $\begin{array}{c}<0.03125 \\
(<0.0943 \\
\mu \mathrm{M})\end{array}$ & $\begin{array}{c}<0.03125 \\
(<0.0943 \\
\mu \mathrm{M})\end{array}$ \\
\hline
\end{tabular}

${ }^{1} \mathrm{WT}$, wild-type; ${ }^{2} \mathrm{CP}$, ciprofloxacin.

To investigate whether the observed antibacterial activities of these hybrids is due to their interactions with the catalytic or the ATP binding sites of DNA gyrase, or both, we tested them against three E. coli MG1655 strains in the presence of an efflux-pump substrate phenylalanine-arginine $\beta$-naphthylamide $(\mathrm{PA} \beta \mathrm{N})$ : wild-type; a GyrB R136C mutant carrying a mutation at the ATP binding site; and the GyrA S83L, D87N and ParC S80I, E84G mutants, with the fluoroquinolone-binding site mutated (Table 4). These mutated amino acids are the most common sites for target-based resistance in E. coli. The results for these mutant strains confirm the hypothesis that these compounds can interact with both subunits; i.e., GyrA (and/or ParC) and GyrB. Compound 7b showed equipotent antibacterial activities against the strain with a mutated GyrB binding site and against the strain with the mutated fluoroquinolone binding site (GyrA and ParC). The activities against the two mutants were also comparable for compounds $\mathbf{7 a}$ and $\mathbf{1 1} \mathbf{b}$, which suggests that $7 \mathbf{a}, 7 \mathbf{b}$, and $\mathbf{1 1 b}$ have a balanced interaction with both of the binding sites. For $3 \mathbf{a}$ and 11a, the mutation in the GyrB binding site did not result in weaker activities compared to the wild type, while the mutation at the fluoroquinolone binding site did; this indicated that these two compounds interacted more strongly with the GyrA and ParC subunits. Nevertheless, the activities for this mutant were not completely lost. From these data, it can be concluded that our new hybrids can interact with both the GyrA and GyrB binding sites. 
Table 4. Minimum inhibitory concentrations of these new hybrid compounds against the three indicated E. coli MG1655 strains. The assays were carried out in the presence of $50 \mu \mathrm{g} / \mathrm{mL}$ PA $\beta N$.

\begin{tabular}{|c|c|c|c|}
\hline \multirow[b]{2}{*}{ Cpd. } & \multicolumn{3}{|c|}{ Minimum Inhibitory Concentration $[\mu \mathrm{g} / \mathrm{mL}]$} \\
\hline & E. coli MG1655 WT ${ }^{1}$ & $\begin{array}{c}\text { E. coli MG1655 GyrB } \\
\text { R136C }\end{array}$ & $\begin{array}{l}\text { E. coli MG1655 GyrA } \\
\text { S83L, D87N ParC } \\
\text { S80I, E84G }\end{array}$ \\
\hline 3a & $\begin{array}{c}0.5 \\
(0.73 \mu \mathrm{M})\end{array}$ & $\begin{array}{c}0.5 \\
(0.73 \mu \mathrm{M})\end{array}$ & $\begin{array}{c}16 \\
(23.4 \mu \mathrm{M})\end{array}$ \\
\hline $3 b$ & $\begin{array}{c}64 \\
(81.0 \mu \mathrm{M})\end{array}$ & $\begin{array}{c}32 \\
(40.5 \mu \mathrm{M})\end{array}$ & $\begin{array}{c}>64 \\
(>81.0 \mu \mathrm{M})\end{array}$ \\
\hline $7 a$ & $\begin{array}{c}1 \\
(1.35 \mu \mathrm{M})\end{array}$ & $\begin{array}{c}2 \\
(2.70 \mu \mathrm{M})\end{array}$ & $\begin{array}{c}0.5 \\
(0.675 \mu \mathrm{M})\end{array}$ \\
\hline $7 \mathrm{~b}$ & $\begin{array}{c}1 \\
(1.325 \mu \mathrm{M})\end{array}$ & $\begin{array}{c}1 \\
(1.325 \mu \mathrm{M})\end{array}$ & $\begin{array}{c}1 \\
(1.325 \mu \mathrm{M})\end{array}$ \\
\hline $11 \mathrm{a}$ & $\begin{array}{c}0.5 \\
(0.65 \mu \mathrm{M})\end{array}$ & $\begin{array}{c}0.5 \\
(0.65 \mu \mathrm{M})\end{array}$ & $\begin{array}{c}8 \\
(10.4 \mu \mathrm{M})\end{array}$ \\
\hline $11 b$ & $\begin{array}{c}1 \\
(1.14 \mu \mathrm{M})\end{array}$ & $\begin{array}{c}2 \\
(2.28 \mu \mathrm{M})\end{array}$ & $\begin{array}{c}4 \\
(4.56 \mu \mathrm{M})\end{array}$ \\
\hline $\mathrm{CP}^{2}$ & $\begin{array}{c}<0.03125 \\
(<0.0943 \mu \mathrm{M})\end{array}$ & $\begin{array}{c}<0.03125 \\
(<0.0943 \mu \mathrm{M})\end{array}$ & $\begin{array}{c}64 \\
(193 \mu \mathrm{M})\end{array}$ \\
\hline
\end{tabular}

${ }^{1} \mathrm{WT}$, wild type; ${ }^{2} \mathrm{CP}$, ciprofloxacin

\section{Conclusions}

In summary, we have designed and synthesized new hybrid ligands that can interact with both the catalytic and the ATP binding sites of DNA gyrase. These new hybrids show low nanomolar inhibitory activities on E. coli DNA gyrase, and good antibacterial activities, especially against K. pneumoniae and E. coli, two pathogens from the problematic ESKAPE group. Additionally, compounds $\mathbf{3 a}$ and $\mathbf{1 1} \mathbf{b}$ do not undergo extensive efflux. Testing of these compounds on mutant $E$. coli strains confirmed that they can bind to both the GyrA (and/or ParC) and GyrB binding sites. Targeting both of the binding sites results in potent antibacterial activities against Gram-negative pathogens, and should also have a strong advantage in terms of delayed or prevented emergence of bacterial resistance.

Supplementary Materials: The following are available online at https: / www.mdpi.com/1999-4 923/13/1/6/s1: Figure S1. Dose-response curves for compounds $\mathbf{3 a}, \mathbf{3 b}, \mathbf{7} \mathbf{a}, \mathbf{7 b}, \mathbf{1 1} \mathbf{a}$, and $\mathbf{1 1} \mathbf{b}$ for E. coli DNA gyrase, Figure S2. Dose-response curves for compounds $\mathbf{3 a}, \mathbf{7 a}, \mathbf{7 b}$, and $\mathbf{1 1} \mathbf{b}$ for E. coli topoisomerase IV, Figure S3. ${ }^{1} \mathrm{H}$ NMR spectra of compound 3a, Figure S4. HPLC chromatogram of compound 3a, Figure S5. ${ }^{1} \mathrm{H}$ NMR spectra of compound 3b, Figure S6. HPLC chromatogram of compound $3 \mathbf{b}$, Figure S7. ${ }^{1} \mathrm{H}$ NMR spectra of compound 7a, Figure S8. HPLC chromatogram of compound 7a, Figure S9. ${ }^{1} \mathrm{H}$ NMR spectra of compound $\mathbf{7 b}$, Figure S10. HPLC chromatogram of compound 7b, Figure S11. ${ }^{1} \mathrm{H}$ NMR spectra of compound 11a, Figure S12. HPLC chromatogram of compound 11a, Figure S13. ${ }^{1} \mathrm{H}$ NMR spectra of compound 11b, Figure S14. HPLC chromatogram of compound 11b.

Author Contributions: Conceptualization, L.P.M. and T.T.; methodology, M.D., Ž.S., J.I., N.Z., A.Z., P.É.S., A.N., G.D., T.R., C.P., D.K., L.P.M. and T.T.; software, T.T.; validation, M.D., P.É.S., A.N., G.D., T.R. and T.T.; investigation, M.D., Ž.S., P.É.S., G.D. and T.R.; writing—original draft preparation, M.D. and T.T.; writing-review and editing, M.D., T.T. and L.P.M.; visualization, M.D. and T.T.; supervision, L.P.M. and T.T.; funding acquisition, D.K. and C.P. All authors have read and agreed to the published version of the manuscript.

Funding: This study was funded by the Slovenian Research Agency (Grant No. P1-0208) and supported by the following research grants: European Research Council H2020-ERC-2014-CoG 648364-Resistance Evolution (C.P.); 'Célzott Lendület' Programme of the Hungarian Academy of Sciences LP-2017-10/2017 (C.P.); 'Élvonal' KKP 126506 (C.P.), GINOP-2.3.2-15-2016-00014 (EVOMER, for C.P.), GINOP-2.3.2-15-2016-00020 (MolMedEx TUMORDNS) and GINOP-2.3.3-15-2016-00001, 
EFOP 3.6.3-VEKOP-16-2017-00009 (P.Sz, T.R.), UNKP-20-3 New National Excellence Programme of the Ministry for Innovation and Technology (P.Sz.), and a PhD Fellowship from the Boehringer Ingelheim Fonds (A.N.).

Institutional Review Board Statement: Not applicable.

Informed Consent Statement: Not applicable.

Data Availability Statement: The data presented in this study are available at www.mdpi.com/xxx/ s1.

Acknowledgments: The authors thank Chris Berrie for editing the manuscript.

Conflicts of Interest: The authors declare the following financial interests/personal relationships which might be considered as potential competing interests: a PCT patent application (New class of DNA gyrase and/or topoisomerase IV inhibitors with activity against gram-positive and gramnegative bacteria: PCT/EP2019/073412073412073412) has been filed by Tomašič, N.T., Zidar, M., Durcik, J., Ilaš, A., Zega, C., Cruz, PD., Tammela, C., Pál, A., Nyerges, D., Kikelj, L., Mašič, P. The funders had no role in the design of the study, in the collection, analyses, or interpretation of the data, in the writing of the manuscript, or in the decision to publish the results.

\section{Appendix A}

\section{Appendix A.1. Synthetic Procedures and Analytical Data}

General procedure A. Synthesis of compounds $\mathbf{3 a - b}, \mathbf{5 a}-\mathbf{b}, \mathbf{7} \mathbf{a}-\mathbf{b}$, and 11a-b (with 3a as the example). A solution of 2-(3,4-dichloro-5-methyl-1H-pyrrole-2-carboxamido)benzo[d] thiazole-6-carboxylic acid (1a, $75 \mathrm{mg}, 0.203 \mathrm{mmol})$ in $N, N$-dimethylformamide $(8 \mathrm{~mL})$ was cooled to $0{ }^{\circ} \mathrm{C}$, and then EDC (47 mg, $\left.0.244 \mathrm{mmol}\right), \mathrm{HOBt}(36 \mathrm{mg}, 0.264 \mathrm{mmol})$, and $\mathrm{N}$-methylmorpholine $(45 \mu \mathrm{L}, 0.406 \mathrm{mmol})$ were added, and the reaction mixture was stirred for $30 \mathrm{~min}$ at $0{ }^{\circ} \mathrm{C}$. Ciprofloxacin $(2,67 \mathrm{mg}, 0.203 \mathrm{mmol})$ was then added, and the reaction mixture was stirred at room temperature overnight. The solvent was evaporated in vacuo, with ethyl acetate $(30 \mathrm{~mL})$ and $10 \%$ citric acid $(20 \mathrm{~mL})$ added to the residue. The precipitate obtained was filtered off, washed with ethyl acetate, and dried.

1-Cyclopropyl-7-(4-(2-(3,4-dichloro-5-methyl-1H-pyrrole-2-carboxamido)benzo[ $d]$ thiazole-6-carbonyl)piperazin-1-yl)-6-fluoro-4-oxo-1,4-dihydroquinoline-3-carboxylic acid (3a). Yield: $91 \mathrm{mg}$ (65.7\%); dark purple solid; mp > 300 ${ }^{\circ} \mathrm{C} .{ }^{1} \mathrm{H}$ NMR $(400 \mathrm{MHz}$, DMSO- $\left.d_{6}\right) \delta$ [ppm] 1.15-1.23 (m, 2H, cyclopropyl- $\left.\mathrm{CH}_{2}\right), 1.30-1.37(\mathrm{~m}, 2 \mathrm{H}$, cyclopropyl$\left.\mathrm{CH}_{2}\right), 2.28\left(\mathrm{~s}, 3 \mathrm{H}\right.$, pyrr- $\left.\mathrm{CH}_{3}\right), 3.30-3.45$ (signal is overlapped with the signal for water, $4 \mathrm{H}$, $2 \times$ piperazine- $\left.\mathrm{CH}_{2}\right), 3.65-3.90\left(\mathrm{~m}, 5 \mathrm{H}, 2 \times\right.$ piperazine- $\left.\mathrm{CH}_{2}, \mathrm{CH}\right), 7.58(\mathrm{dd}, 1 \mathrm{H}, J=8.4$, 1.6 Hz, Ar-H'-5), 7.62 (d, 1H, J = 7.6 Hz, Ar-H'-4/Ar-H-8), 7.85 (s, 1H, Ar-H'-4/Ar-H-8), $7.96(\mathrm{~d}, 1 \mathrm{H}, J=13.1 \mathrm{~Hz}, \mathrm{Ar}-\mathrm{H}-5), 8.19$ (s, 1H, Ar-H'-7), 8.69 (s, 1H, Ar-H-2), 11.86 (s, 1H, pyrr-NH/CONH), 12.39 (s, 1H, pyrr-NH/CONH), $15.21(\mathrm{~s}, 1 \mathrm{H}, \mathrm{COOH})$. IR (ATR) $v\left[\mathrm{~cm}^{-1}\right]$ $=3368(\mathrm{NH}), 3173(\mathrm{NH}), 3066(\mathrm{OH}), 1713(\mathrm{CO}), 1663(\mathrm{CO}), 1603,1530,1491,1331,1256$, $1162,1085,1020,944,900,830,809,771,742,706,624,552,517$. HRMS (ESI-) $\mathrm{m} / \mathrm{z}$ for $\mathrm{C}_{31} \mathrm{H}_{24} \mathrm{Cl}_{2} \mathrm{FN}_{6} \mathrm{O}_{5} \mathrm{~S}\left([\mathrm{M}-\mathrm{H}]^{-}\right)$: calculated: 681.0885 , found: 681.0909 , delta: $3.66 \mathrm{ppm}$. HPLC: $t_{\mathrm{r}} 6.86 \mathrm{~min}(95.8 \%$ at $254 \mathrm{~nm})$.

7-(4-(4-(Benzyloxy)-2-(3,4-dichloro-5-methyl-1H-pyrrole-2-carboxamido)benzo[d] thiazole-6-carbonyl)piperazin-1-yl)-1-cyclopropyl-6-fluoro-4-oxo-1,4-dihydroquinoline3-carboxylic acid (3b). Synthesized according to General procedure A using $1 \mathrm{~b}(60 \mathrm{mg}$, $0.162 \mathrm{mmol}$ ) as reactant instead of 1a. The crude product was purified with flash column chromatography using dichloromethane/methanol (15:1) as eluent. Yield: $20 \mathrm{mg}$ (20.1\%); white solid; mp > $300{ }^{\circ} \mathrm{C} .{ }^{1} \mathrm{H}$ NMR $\left(400 \mathrm{MHz}\right.$, DMSO- $\left.d_{6}\right) \delta[\mathrm{ppm}] 1.19$ (s, 2H, cyclopropyl- $\left.\mathrm{CH}_{2}\right), 1.28-1.36\left(\mathrm{~m}, 2 \mathrm{H}\right.$, cyclopropyl- $\left.\mathrm{CH}_{2}\right), 2.26\left(\mathrm{~s}, 3 \mathrm{H}\right.$, pyrr- $\left.-\mathrm{CH}_{3}\right), 3.39(\mathrm{~s}, 4 \mathrm{H}$, $2 \times$ piperazine- $\left.\mathrm{CH}_{2}\right), 3.58-3.94\left(\mathrm{~m}, 5 \mathrm{H}, 2 \times\right.$ piperazine- $\left.\mathrm{CH}_{2}, \mathrm{CH}\right), 5.32\left(\mathrm{~s}, 2 \mathrm{H}, \mathrm{CH}_{2} \mathrm{Bn}\right), 7.19$ (s, 1H, Ar-H'-5), 7.29-7.48 (m, 3H, $3 \times$ Ar-H" (Bn)), 7.48-7.57 (m, 2H, $2 \times$ Ar-H" (Bn)), 7.61 $(\mathrm{d}, J=7.4 \mathrm{~Hz}, 1 \mathrm{H}, \mathrm{Ar}-\mathrm{H}-8), 7.74\left(\mathrm{~s}, 1 \mathrm{H}, \mathrm{Ar}-\mathrm{H}^{\prime}-7\right), 7.95$ (d, $\left.J=13.1 \mathrm{~Hz}, 1 \mathrm{H}, \mathrm{Ar}-\mathrm{H}-5\right), 8.68$ (s, $1 \mathrm{H}, \mathrm{Ar}-\mathrm{H}-2), 12.06$ (s, 1H, pyrr-NH/CONH), $12.22(\mathrm{~s}, 1 \mathrm{H}$, pyrr-NH/CONH), 15.19 (s, 1H, $\mathrm{COOH})$. IR (ATR) $v\left[\mathrm{~cm}^{-1}\right]=2915(\mathrm{NH}), 2843(\mathrm{OH}), 1723(\mathrm{CO}), 1658(\mathrm{CO}), 1626,1531,1471$, $1402,1331,1258,1131,1029,902,743,617,551$. HRMS $\left(\mathrm{ESI}^{+}\right) \mathrm{m} / z$ for $\mathrm{C}_{38} \mathrm{H}_{32} \mathrm{Cl}_{2} \mathrm{FN}_{6} \mathrm{O}_{6} \mathrm{~S}([\mathrm{M}$ 
$\left.+\mathrm{H}]^{+}\right)$: calculated 789.1460 , found 789.1401 , delta: $-7.42 \mathrm{ppm}$. HPLC: $t_{\mathrm{r}} 7.48 \mathrm{~min}(98.9 \%$ at $254 \mathrm{~nm})$.

7-(4-((tert-Butoxycarbonyl)glycyl)piperazin-1-yl)-1-cyclopropyl-6-fluoro-4-oxo-1, 4-dihydroquinoline-3-carboxylic acid (5a). Synthesized according to General procedure A using (tert-butoxycarbonyl)glycine $(185 \mathrm{mg}, 1.06 \mathrm{mmol})$ as reactant. During isolation, the phases of the mother liquor after the filtration of the precipitated product were separated, where the water phase was extracted with ethyl acetate $(2 \times 20 \mathrm{~mL})$, and the organic phases were combined and washed with $10 \%$ citric acid $(2 \times 10 \mathrm{~mL})$ and brine $(20 \mathrm{~mL})$. The organic phase was dried over $\mathrm{Na}_{2} \mathrm{SO}_{4}$ and filtered, and the solvent was removed in vacuo. The crude product was purified first by crystallization from methanol, where the mother liquor was evaporated, and the residue was purified again by crystallization from a methanol/diethyl ether mixture. All three precipitates were combined to give $148 \mathrm{mg}$ of pure product. Yield: $148 \mathrm{mg}(28.7 \%)$; pale yellow solid; mp $218-220{ }^{\circ} \mathrm{C} .{ }^{1} \mathrm{H}$ NMR $\left(400 \mathrm{MHz}\right.$, DMSO- $\left.d_{6}\right) \delta[\mathrm{ppm}]$ 1.15-1.23 $\left(\mathrm{m}, 2 \mathrm{H}\right.$, cyclopropyl- $\left.\mathrm{CH}_{2}\right), 1.28-1.35(\mathrm{~m}, 2 \mathrm{H}$, cyclopropyl- $\left.\mathrm{CH}_{2}\right), 1.39\left(\mathrm{~s}, 9 \mathrm{H}, 3 \times \mathrm{CH}_{3}(t-\mathrm{Bu})\right), 3.28-3.40$ (signal is overlapped with the signal for water, $4 \mathrm{H}, 2 \times$ piperazine- $\left.\mathrm{CH}_{2}\right), 3.67\left(\mathrm{br} \mathrm{s}, 4 \mathrm{H}, 2 \times\right.$ piperazine- $\left.\mathrm{CH}_{2}\right), 3.79-3.89$ $\left(\mathrm{m}, 3 \mathrm{H}, \mathrm{CH}_{2} \mathrm{CO}, \mathrm{CH}\right), 6.84(\mathrm{t}, 1 \mathrm{H}, J=5.6 \mathrm{~Hz}, \mathrm{NH}), 7.59(\mathrm{~d}, 1 \mathrm{H}, J=7.4 \mathrm{~Hz}, \mathrm{Ar}-\mathrm{H}-8), 7.95$ $(\mathrm{d}, 1 \mathrm{H}, J=13.2 \mathrm{~Hz}, \mathrm{Ar}-\mathrm{H}-5), 8.68(\mathrm{~s}, 1 \mathrm{H}, \mathrm{Ar}-\mathrm{H}-2), 15.20(\mathrm{~s}, 1 \mathrm{H}, \mathrm{COOH})$. IR (ATR) $v\left[\mathrm{~cm}^{-1}\right]$ $=3406(\mathrm{NH}), 3001(\mathrm{OH}), 1729(\mathrm{CO}), 1702(\mathrm{CO}), 1650(\mathrm{CO}), 1622,1496,1468,1439,1387$, $1341,1298,1243,1217,1164,1098,1054,1017,917,931,871,833,781,750,709,618,582$. MS $\left(\mathrm{ESI}^{+}\right) \mathrm{m} / z=489.3\left([\mathrm{M}+\mathrm{H}]^{+}\right)$. HRMS $\left(\mathrm{ESI}^{+}\right) \mathrm{m} / z$ for $\mathrm{C}_{24} \mathrm{H}_{30} \mathrm{FN}_{4} \mathrm{O}_{6}\left([\mathrm{M}+\mathrm{H}]^{+}\right)$: calculated: 489.2144, found: 489.2130 , delta: $-2.80 \mathrm{ppm}$.

7-(4-(3-((tert-Butoxycarbonyl)amino)propanoyl)piperazin-1-yl)-1-cyclopropyl-

6-fluoro-4-oxo-1,4-dihydroquinoline-3-carboxylic acid (5b). Synthesized according to General procedure A using 3-((tert-butoxycarbonyl)amino)propanoic acid (171 mg, 0.91 $\mathrm{mmol}$ ) as reactant. During isolation, the phases of the mother liquor after filtration of precipitated product were separated, where water phase was extracted with ethyl acetate $(2 \times 20 \mathrm{~mL})$, and the organic phases were combined and washed with $10 \%$ citric acid $(2 \times$ $10 \mathrm{~mL}$ ) and brine $(20 \mathrm{~mL})$. The organic phase was dried over $\mathrm{Na}_{2} \mathrm{SO}_{4}$ and filtered, and the solvent was removed in vacuo. The crude product was purified by crystallization from methanol. The two precipitates were combined to give $243 \mathrm{mg}$ of pure product. Yield: $243 \mathrm{mg}$ (53.4\%); pale yellow crystals; mp 185-187 ${ }^{\circ} \mathrm{C} .{ }^{1} \mathrm{H}$ NMR $\left(400 \mathrm{MHz}, \mathrm{DMSO}-d_{6}\right) \delta$ [ppm] 1.17-1.23 (m, 2H, cyclopropyl- $\left.\mathrm{CH}_{2}\right), 1.29-1.36\left(\mathrm{~m}, 2 \mathrm{H}\right.$, cyclopropyl- $\left.\mathrm{CH}_{2}\right), 1.38(\mathrm{~s}$, $\left.9 \mathrm{H}, 3 \times \mathrm{CH}_{3}(t-\mathrm{Bu})\right), 3.18\left(\mathrm{q}, 2 \mathrm{H}, J=6.8 \mathrm{~Hz}, \mathrm{NHCH}_{2} \mathrm{CH}_{2}\right), 3.29-3.42$ (signal is overlapped with the signal for water, $6 \mathrm{H}, 2 \times$ piperazine- $\left.\mathrm{CH}_{2}, \mathrm{NHCH}_{2} \mathrm{CH}_{2}\right), 3.64-3.73(\mathrm{~m}, 4 \mathrm{H}, 2 \times$ piperazine- $\left.\mathrm{CH}_{2}\right), 3.83(\mathrm{sept}, 1 \mathrm{H}, J=4.1 \mathrm{~Hz}, \mathrm{CH}), 6.77\left(\mathrm{t}, 1 \mathrm{H}, J=5.6 \mathrm{~Hz}, \mathrm{CONHCH}_{2}\right), 7.59$ (d, $1 \mathrm{H}, J=7.5 \mathrm{~Hz}, \mathrm{Ar}-\mathrm{H}-8), 7.95$ (d, 1H, J = 13.2 Hz, Ar-H-5), 8.68 (s, 1H, Ar-H-2), 15.21 (s, $1 \mathrm{H}, \mathrm{COOH})$. IR (ATR) $v\left[\mathrm{~cm}^{-1}\right]=3272(\mathrm{NH}), 2985(\mathrm{OH}), 1732(\mathrm{CO}), 1700(\mathrm{CO}), 1623(\mathrm{CO})$, 1503, 1470, 1382, 1343, 1260, 1237, 1169, 1107, 1056, 1020, 966, 933, 876, 833, 803, 780, 747, 699, 666, 636, 564. MS $\left(\mathrm{ESI}^{+}\right) \mathrm{m} / \mathrm{z}=503.3\left([\mathrm{M}+\mathrm{H}]^{+}\right)$. HRMS $\left(\mathrm{ESI}^{+}\right) \mathrm{m} / z$ for $\mathrm{C}_{25} \mathrm{H}_{32} \mathrm{FN}_{4} \mathrm{O}_{6}$ $\left([\mathrm{M}+\mathrm{H}]^{+}\right)$: calculated: 503.2300, found: 503.2290 , delta: $-2.16 \mathrm{ppm}$.

General procedure B. Synthesis of compounds $\mathbf{6 a}-\mathbf{b}$ and $\mathbf{1 0}$ (with $\mathbf{6 a}$ as the example). Compound 5 a $(171 \mathrm{mg}, 0.350 \mathrm{mmol}, 1$ equiv.) was suspended in 1,4-dioxane $(5 \mathrm{~mL})$ and stirred at room temperature for $5 \mathrm{~min}$. Then, $4 \mathrm{M} \mathrm{HCl}$ in 1,4-dioxane $(6 \mathrm{~mL})$ was added, and the reaction mixture was stirred at room temperature for $3 \mathrm{~h}$. The solvent was removed in vacuo, and the crude product was purified with crystallization from a methanol/diethyl ether mixture, and dried.

2-(4-(3-Carboxy-1-cyclopropyl-6-fluoro-4-oxo-1,4-dihydroquinolin-7-yl)piperazin -1-yl)-2-oxoethan-1-aminium chloride (6a). Yield: $95 \mathrm{mg}$ (63.9\%); yellow powder; $\mathrm{mp}$ $178-180{ }^{\circ} \mathrm{C} .{ }^{1} \mathrm{H}$ NMR $\left(400 \mathrm{MHz}, \mathrm{DMSO}-d_{6}\right) \delta$ [ppm] 1.17-1.23 (m, 2H, cyclopropyl- $\left.\mathrm{CH}_{2}\right)$, $1.27-1.35\left(\mathrm{~m}, 2 \mathrm{H}\right.$, cyclopropyl- $\left.\mathrm{CH}_{2}\right), 3.22-3.54$ (signal is overlapped with the signal for water, $4 \mathrm{H}, 2 \times$ piperazine- $\left.\mathrm{CH}_{2}\right), 3.59-3.65\left(\mathrm{~m}, 2 \mathrm{H}\right.$, piperazine- $\left.\mathrm{CH}_{2}\right), 3.72-3.78(\mathrm{~m}, 2 \mathrm{H}$, piperazine- $\left.\mathrm{CH}_{2}\right), 3.83(\mathrm{sept}, 1 \mathrm{H}, J=4.0 \mathrm{~Hz}, \mathrm{CH}), 3.92-3.40\left(\mathrm{~m}, 2 \mathrm{H}, \mathrm{CH}_{2} \mathrm{NH}_{3}{ }^{+}\right), 7.59(\mathrm{~d}, 1 \mathrm{H}, J$ $=7.5 \mathrm{~Hz}, \mathrm{Ar}-\mathrm{H}-8), 7.97(\mathrm{~d}, 1 \mathrm{H}, J=13.1 \mathrm{~Hz}, \mathrm{Ar}-\mathrm{H}-5), 8.10\left(\mathrm{~s}, 3 \mathrm{H}, \mathrm{NH}_{3}{ }^{+}\right), 8.69(\mathrm{~s}, 1 \mathrm{H}, \mathrm{Ar}-\mathrm{H}-2)$, 
$15.19(\mathrm{~s}, 1 \mathrm{H}, \mathrm{COOH})$. IR (ATR) $v\left[\mathrm{~cm}^{-1}\right]=3395(\mathrm{NH}), 2921(\mathrm{OH}), 2863(\mathrm{CH}), 2631(\mathrm{CH})$, 1719 (CO), 1659 (CO), 1624 (CO), 1493, 1452, 1386, 1336, 1304, 1245, 1146, 1056, 1018, 949, $923,886,830,805,747,705,645,615,530 . \mathrm{MS}\left(\mathrm{ESI}^{+}\right) \mathrm{m} / z=389.2\left([\mathrm{M}+\mathrm{H}]^{+}\right) . \mathrm{HRMS}\left(\mathrm{ESI}^{+}\right)$ $m / z$ for $\mathrm{C}_{19} \mathrm{H}_{22} \mathrm{FN}_{4} \mathrm{O}_{4}\left([\mathrm{M}+\mathrm{H}]^{+}\right)$: calculated: 389.1620 , found: 389.1612 , delta: -1.93 ppm.

3-(4-(3-Carboxy-1-cyclopropyl-6-fluoro-4-oxo-1,4-dihydroquinolin-7-yl)piperazin-1yl)-3-oxopropan-1-aminium chloride (6b). Synthesized according to General procedure B. Yield: $142 \mathrm{mg}$ (77.1\%); pale yellow powder; mp 207-209 ${ }^{\circ} \mathrm{C} .{ }^{1} \mathrm{H}$ NMR (400 MHz, DMSO$\left.d_{6}\right) \delta[\mathrm{ppm}] 1.16-1.24\left(\mathrm{~m}, 2 \mathrm{H}\right.$, cyclopropyl- $\left.\mathrm{CH}_{2}\right), 1.28-1.35\left(\mathrm{~m}, 2 \mathrm{H}\right.$, cyclopropyl- $\left.\mathrm{CH}_{2}\right)$, $2.75\left(\mathrm{t}, 2 \mathrm{H}, \mathrm{J}=6.4 \mathrm{~Hz}, \mathrm{NH}_{3}{ }^{+} \mathrm{CH}_{2} \mathrm{CH}_{2}\right), 2.98-3.10\left(\mathrm{~m}, 2 \mathrm{H}, \mathrm{NH}_{3}{ }^{+} \mathrm{CH}_{2} \mathrm{CH}_{2}\right.$ ), 3.29-3.50 (signal is overlapped with the signal for water, $4 \mathrm{H}, 2 \times$ piperazine- $\left.\mathrm{CH}_{2}\right), 3.63-3.70(\mathrm{~m}, 2 \mathrm{H}$, piperazine- $\left.\mathrm{CH}_{2}\right), 3.70-3.76\left(\mathrm{~m}, 2 \mathrm{H}\right.$, piperazine- $\left.\mathrm{CH}_{2}\right), 3.83($ sept $, 1 \mathrm{H}, J=4.0 \mathrm{~Hz}, \mathrm{CH}), 7.58(\mathrm{~d}$, $1 \mathrm{H}, J=7.5 \mathrm{~Hz}, \mathrm{Ar}-\mathrm{H}-8), 7.77$ (br s, 3H, NH $3+$ ), 7.96 (d, 1H, J = 13.2 Hz, Ar-H-5), 8.69 (s, 1H, Ar-H-2), 15.19 (s, 1H, COOH). IR (ATR) v [ $\left.\mathrm{cm}^{-1}\right]=3459(\mathrm{NH}), 3233(\mathrm{NH}), 3058(\mathrm{OH}), 2953$, 2849 (CH), 1700 (CO), 1621 (CO), 1477, 1443, 1332, 1246, 1216, 1188, 1143, 1107, 1044, 1023, 988, 947, 930, 873, 833, 808, 750, 626, 539. MS $\left(\mathrm{ESI}^{+}\right) \mathrm{m} / z=403.1\left([\mathrm{M}+\mathrm{H}]^{+}\right) . \mathrm{HRMS}\left(\mathrm{ESI}^{+}\right)$ $m / z$ for $\mathrm{C}_{20} \mathrm{H}_{24} \mathrm{FN}_{4} \mathrm{O}_{4}\left([\mathrm{M}+\mathrm{H}]^{+}\right)$: calculated: 403.1776 , found: 403.1769 , delta: $-1.71 \mathrm{ppm}$.

1-Cyclopropyl-7-(4-((2-(3,4-dichloro-5-methyl-1H-pyrrole-2-carboxamido)benzo[d] thiazole-6-carbonyl)glycyl)piperazin-1-yl)-6-fluoro-4-oxo-1,4-dihydroquinoline-3-

carboxylic acid (7a). Synthesized according to General procedure A with $1 \mathrm{a}(61 \mathrm{mg}$, $0.165 \mathrm{mmol})$ and $6 \mathrm{a}(70 \mathrm{mg}, 0.165 \mathrm{mmol})$ as reactants and 3 equiv. of $N$-methylmorpholine (54 $\mu \mathrm{L}, 0.495 \mathrm{mmol}$ ) instead of 2 equiv. The precipitate after filtration was resuspended in methanol, sonicated, heated, and filtered off. The procedure was repeated twice. Yield: $29.5 \mathrm{mg}$ (24.2\%); light grey powder; $\mathrm{mp}>300{ }^{\circ} \mathrm{C} .{ }^{1} \mathrm{H}$ NMR $\left(400 \mathrm{MHz}, \mathrm{DMSO}-d_{6}\right) \delta$ [ppm] 1.16-1.23 (m, 2H, cyclopropyl- $\left.\mathrm{CH}_{2}\right), 1.28-1.36\left(\mathrm{~m}, 2 \mathrm{H}\right.$, cyclopropyl- $\left.\mathrm{CH}_{2}\right), 2.28$ (s, 3H, pyrr$\left.\mathrm{CH}_{3}\right), 3.42\left(\mathrm{~s}, 4 \mathrm{H}, 2 \times\right.$ piperazine- $\left.\mathrm{CH}_{2}\right), 3.69-3.78\left(\mathrm{~m}, 4 \mathrm{H}, 2 \times\right.$ piperazine- $\left.\mathrm{CH}_{2}\right), 3.84(\mathrm{~s}, 1 \mathrm{H}$, $\mathrm{CH}), 4.25\left(\mathrm{~d}, 2 \mathrm{H}, J=5.4 \mathrm{~Hz}, \mathrm{NHCH}_{2} \mathrm{CO}\right), 7.61$ (d, 1H, J = 7.4 Hz, Ar-H'-4/Ar-H-8), 7.82 (s, 1H, Ar-H), 7.93-8.02 (m, 2H, $2 \times$ Ar-H), 8.53 (s, 1H, Ar-H), 8.68 (s, 1H, Ar-H-2), 8.69-8.72 (m, 1H, ArCONH), 11.93 (s, 1H, pyrr-NH/pyrr-CONH), 12.35 (s, 1H, pyrr-NH/pyrr-CONH), $15.21(\mathrm{~s}, 1 \mathrm{H}, \mathrm{COOH})$. IR $(\mathrm{ATR}) v\left[\mathrm{~cm}^{-1}\right]=3361(\mathrm{NH}), 3232(\mathrm{NH}), 2989(\mathrm{OH}), 1712(\mathrm{CO})$, 1660 (CO), 1625 (CO), 1504, 1449, 1331, 1253, 1024, 938, 888, 831, 765, 746, 701, 619. HRMS $\left(\mathrm{ESI}^{+}\right) \mathrm{m} / z$ for $\mathrm{C}_{33} \mathrm{H}_{29} \mathrm{Cl}_{2} \mathrm{FN}_{7} \mathrm{O}_{6} \mathrm{~S}\left([\mathrm{M}+\mathrm{H}]^{+}\right)$: calculated: 740.1256 , found: 740.1226 , delta: $-3.98 \mathrm{ppm}$. HPLC: $t_{\mathrm{r}} 6.44 \mathrm{~min}(95.0 \%$ at $254 \mathrm{~nm})$.

1-Cyclopropyl-7-(4-(3-(2-(3,4-dichloro-5-methyl-1H-pyrrole-2-carboxamido) benzo[d]thiazole-6-carboxamido)propanoyl)piperazin-1-yl)-6-fluoro-4-oxo-1, 4-dihydroquinoline-3-carboxylic acid (7b). Synthesized according to General procedure A with $1 \mathrm{a}(50 \mathrm{mg}, 0.135 \mathrm{mmol})$ and $6 \mathrm{~b}(59 \mathrm{mg}, 0.135 \mathrm{mmol})$ as reactants and 3 equiv. of $N$-methylmorpholine $(45 \mu \mathrm{L}, 0.405 \mathrm{mmol})$ instead of 2 equiv. The precipitate after filtration was suspended in water, sonicated, and filtered off, washed with hot tetrahydrofuran and dried. Yield: $63 \mathrm{mg}$ (61.5\%); brown solid; $\mathrm{mp}>300{ }^{\circ} \mathrm{C} .{ }^{1} \mathrm{H}$ NMR (400 MHz, DMSO- $\left.d_{6}\right) \delta$ [ppm] 1.14-1.22 (m, 2H, cyclopropyl- $\left.\mathrm{CH}_{2}\right), 1.24-1.36\left(\mathrm{~m}, 2 \mathrm{H}\right.$, cyclopropyl- $\left.\mathrm{CH}_{2}\right), 2.28$ (s, $3 \mathrm{H}$, pyrr- $\mathrm{CH}_{3}$ ), $2.72\left(\mathrm{t}, 2 \mathrm{H}, \mathrm{J}=7.1 \mathrm{~Hz}, \mathrm{NHCH}_{2} \mathrm{CH}_{2} \mathrm{CO}\right.$ ), 3.32 (signal is overlapped with the signal for water, $4 \mathrm{H}, 2 \times$ piperazine- $\left.\mathrm{CH}_{2}\right), 3.53-3.58\left(\mathrm{~m}, 2 \mathrm{H}, \mathrm{NHCH}_{2} \mathrm{CH}_{2} \mathrm{CO}\right), 3.72(\mathrm{~s}, 4 \mathrm{H}$, $2 \times$ piperazine- $\left.\mathrm{CH}_{2}\right), 3.80(\mathrm{~s}, 1 \mathrm{H}, \mathrm{CH}), 7.54\left(\mathrm{~d}, 1 \mathrm{H}, J=7.4 \mathrm{~Hz}, \mathrm{Ar}-\mathrm{H}^{\prime}-4 / \mathrm{Ar}-\mathrm{H}-8\right), 7.79(\mathrm{~s}, 1 \mathrm{H}$, Ar-H), 7.89-7.99 (m, 2H, $2 \times$ Ar-H), 8.48 (s, 1H, Ar-H), 8.63 (t, 1H, J = 4.0 Hz, ArCONH), 8.67 (s, 1H, Ar-H-2), 11.90 (s, 1H, pyrr-NH/pyrr-CONH), 12.33 (s, 1H, pyrr-NH/pyrr-CONH), $15.20(\mathrm{~s}, 1 \mathrm{H}, \mathrm{COOH})$. IR (ATR) $v\left[\mathrm{~cm}^{-1}\right]=3382(\mathrm{NH}), 3205(\mathrm{NH}), 3002(\mathrm{OH}), 1721(\mathrm{CO})$, 1625 (CO), 1508, 1448, 1408, 1372, 1260, 1089, 1025, 887, 807, 767, 743, 699, 621, 573, 521. HRMS $\left(\mathrm{ESI}^{+}\right) \mathrm{m} / z$ for $\mathrm{C}_{34} \mathrm{H}_{31} \mathrm{Cl}_{2} \mathrm{FN}_{7} \mathrm{O}_{6} \mathrm{~S}\left([\mathrm{M}+\mathrm{H}]^{+}\right)$: calculated: 754.1412 , found: 754.1386 , delta: -3.53 ppm. HPLC: $t_{\mathrm{r}} 6.25 \mathrm{~min}(95.1 \%$ at $254 \mathrm{~nm})$.

7-(4-(2-(2-((tert-Butoxycarbonyl)amino)ethoxy)ethyl)piperazin-1-yl)-1-cyclopropyl6-fluoro-4-oxo-1,4-dihydroquinoline-3-carboxylic acid (9). To a solution of ciprofloxacin (2, $500 \mathrm{mg}, 1.51 \mathrm{mmol})$ in DMF $(33 \mathrm{~mL}), \mathrm{Et}_{3} \mathrm{~N}(694 \mu \mathrm{L}, 4.98 \mathrm{mmol})$ and 2-(2-((tert-butoxycarbonyl)amino)ethoxy)ethyl methanesulfonate $(855 \mathrm{mg}, 3.02 \mathrm{mmol})$ dissolved in $3 \mathrm{~mL}$ of DMF were added, and the reaction mixture was stirred at $80^{\circ} \mathrm{C}$. Then, 5 
drops of water were added, and the reaction mixture was stirred at $80{ }^{\circ} \mathrm{C}$ for 2 days. An additional 1 equiv. of 2-(2-((tert-butoxycarbonyl)amino)ethoxy)ethyl methanesulfonate $(428 \mathrm{mg}, 1.51 \mathrm{mmol})$ dissolved in $3 \mathrm{~mL}$ of DMF and 5 drops of water were added, and the reaction mixture was stirred at $80^{\circ} \mathrm{C}$ overnight. The solvent was removed in vacuo, and ethyl acetate $(200 \mathrm{~mL})$ and water $(100 \mathrm{~mL})$ were added to the residue. The phases were separated, with the organic phase dried over $\mathrm{Na}_{2} \mathrm{SO}_{4}$ and filtered, and the solvent removed in vacuo. The crude product was purified with crystallization from methanol, and then additionally purified by addition of water $(25 \mathrm{~mL})$, with sonication and filtration of the product. The procedure was repeated twice. Yield: $243 \mathrm{mg}$ (31.0\%); pale yellow solid; $\mathrm{mp} 147-150{ }^{\circ} \mathrm{C}$. ${ }^{1} \mathrm{H}$ NMR (400 MHz, DMSO-d 6 ) $\delta$ [ppm] 1.15-1.23 (m, 2H, cyclopropyl- $\left.\mathrm{CH}_{2}\right), 1.29-1.35$ (m, $2 \mathrm{H}$, cyclopropyl- $\left.\mathrm{CH}_{2}\right), 1.38\left(\mathrm{~s}, 9 \mathrm{H}, 3 \times \mathrm{CH}_{3}(t-\mathrm{Bu})\right), 2.57\left(\mathrm{t}, 2 \mathrm{H}, J=5.6 \mathrm{~Hz}, \mathrm{OCH}_{2} \mathrm{CH}_{2} \mathrm{~N}\right)$, 2.66-2.69 (m, 4H, $2 \times$ piperazine- $\left.\mathrm{CH}_{2}\right), 3.09\left(\mathrm{q}, 2 \mathrm{H}, \mathrm{J}=5.6 \mathrm{~Hz}, \mathrm{NHCH}_{2} \mathrm{CH}_{2} \mathrm{O}\right), 3.30-3.43$ (signal is overlapped with the signal for water, $6 \mathrm{H}, 2 \times$ piperazine- $\mathrm{CH}_{2}, \mathrm{OCH}_{2} \mathrm{CH}_{2} \mathrm{~N}$ ), 3.56 $\left(\mathrm{t}, 2 \mathrm{H}, J=5.6 \mathrm{~Hz}, \mathrm{NHCH}_{2} \mathrm{CH}_{2} \mathrm{O}\right.$ ), 3.83 (sept, $\left.1 \mathrm{H}, J=3.6 \mathrm{~Hz}, \mathrm{CH}\right), 8.82(\mathrm{t}, 1 \mathrm{H}, J=5.5 \mathrm{~Hz}$, t-BuOCONH), $7.57(\mathrm{~d}, 1 \mathrm{H}, J=7.5 \mathrm{~Hz}, \mathrm{Ar}-\mathrm{H}-8), 7.92(\mathrm{~d}, 1 \mathrm{H}, J=13.4 \mathrm{~Hz}, \mathrm{Ar}-\mathrm{H}-5), 8.67$ (s, 1H, Ar-H-2), 15.25 (s, 1H, COOH). IR (ATR) v [cm $\left.{ }^{-1}\right]=3231(\mathrm{NH}), 2969(\mathrm{OH}), 1727$ (CO), 1687 (CO), 1628 (CO), 1503, 1451, 1388, 1359, 1338, 1268, 1249, 1166, 1121, 1041, 1027, 1001, 942, 891, 868, 830, 802, 746, 696, 637, 577, 549. MS $\left(\mathrm{ESI}^{+}\right) \mathrm{m} / z=519.4\left([\mathrm{M}+\mathrm{H}]^{+}\right)$. HRMS $\left(\mathrm{ESI}^{+}\right)$ $m / z$ for $\mathrm{C}_{26} \mathrm{H}_{36} \mathrm{FN}_{4} \mathrm{O}_{6}\left([\mathrm{M}+\mathrm{H}]^{+}\right)$: calculated: 519.2613, found: 519.2606, delta: $-1.48 \mathrm{ppm}$.

1-(2-(2-Ammonioethoxy)ethyl)-4-(3-carboxy-1-cyclopropyl-6-fluoro-4-oxo-1,

4-dihydroquinolin-7-yl)piperazin-1-ium chloride (10). Synthesized according to General procedure B. Instead of removing the solvent in vacuo, the formed precipitate was filtered off, washed with 1,4-dioxane (10 mL) and dried. Yield: $230 \mathrm{mg}(100.0 \%)$; grey powder; $\mathrm{mp}$ 176-180 ${ }^{\circ} \mathrm{C} .{ }^{1} \mathrm{H}$ NMR $\left(400 \mathrm{MHz}, \mathrm{DMSO}-d_{6}\right) \delta$ [ppm] 1.13-1.26 (m, 2H, cyclopropyl- $\left.\mathrm{CH}_{2}\right)$, 1.28-1.40 (m, 2H, cyclopropyl- $\left.\mathrm{CH}_{2}\right), 2.97-3.10\left(\mathrm{~m}, 2 \mathrm{H}, \mathrm{CH}_{2}\right), 3.32-3.92$ (signal is overlapped with the signal for water, $\left.15 \mathrm{H}, 7 \times \mathrm{CH}_{2}, \mathrm{CH}\right), 7.63(\mathrm{~d}, 1 \mathrm{H}, J=7.6 \mathrm{~Hz}, \mathrm{Ar}-\mathrm{H}-8), 7.99(\mathrm{~d}, 1 \mathrm{H}, J$ $=13.1 \mathrm{~Hz}, \mathrm{Ar}-\mathrm{H}-5), 8.25\left(\mathrm{~s}, 3 \mathrm{H}, \mathrm{NH}_{3}{ }^{+}\right), 8.71(\mathrm{~s}, 1 \mathrm{H}, \mathrm{Ar}-\mathrm{H}-2), 11.12\left(\mathrm{~s}, 1 \mathrm{H}, \mathrm{NH}^{+}\right)$, signal for COOH group is not seen. IR (ATR) $v\left[\mathrm{~cm}^{-1}\right]=3422(\mathrm{NH}), 3343(\mathrm{NH}), 2971(\mathrm{OH}), 1717(\mathrm{CO})$, 1628 (CO), 1612, 1505, 1485, 1453, 1431, 1376, 1335, 1278, 1111, 1066, 1014, 943, 902, 884, 809, 786, 704, 627, 549. MS (ESI $\left.{ }^{+}\right) m / z=419.2\left([\mathrm{M}+\mathrm{H}]^{+}\right)$. HRMS $\left(\mathrm{ESI}^{+}\right) m / z$ for $\mathrm{C}_{21} \mathrm{H}_{28} \mathrm{FN}_{4} \mathrm{O}_{4}$ $\left([\mathrm{M}+\mathrm{H}]^{+}\right)$: calculated: 419.2089 , found: 419.2082 , delta: $-1.65 \mathrm{ppm}$.

4-(3-Carboxy-1-cyclopropyl-6-fluoro-4-oxo-1,4-dihydroquinolin-7-yl)-1-(2-(2-(2-(3,4dichloro-5-methyl-1H-pyrrole-2-carboxamido)benzo[d]thiazole-6-carboxamido)ethoxy) ethyl)piperazin-1-ium chloride (11a). Synthesized according to General procedure A with 1a $(69 \mathrm{mg}, 0.186 \mathrm{mmol})$ and $10(92 \mathrm{mg}, 0.186 \mathrm{mmol})$ as reactants. After isolation the product was additionally purified by crystallization from methanol. Yield: $36 \mathrm{mg}(25.3 \%)$; light purple solid; mp 187-190 ${ }^{\circ} \mathrm{C} .{ }^{1} \mathrm{H}$ NMR $\left(400 \mathrm{MHz}, \mathrm{DMSO}-d_{6}\right) \delta[\mathrm{ppm}] 1.20-1.27(\mathrm{~m}, 2 \mathrm{H}$, cyclopropyl- $\left.\mathrm{CH}_{2}\right), 1.28-1.35\left(\mathrm{~m}, 2 \mathrm{H}\right.$, cyclopropyl- $\left.\mathrm{CH}_{2}\right), 2.28\left(\mathrm{~s}, 3 \mathrm{H}\right.$, pyrr- $\left.\mathrm{CH}_{3}\right), 3.12-3.31$ $\left(\mathrm{m}, 4 \mathrm{H}, 2 \times \mathrm{CH}_{2}\right), 3.39-3.84\left(\mathrm{~s}, 4 \mathrm{H}, 2 \times \mathrm{CH}_{2}\right) 3.52-3.61\left(\mathrm{~m}, 4 \mathrm{H}, 2 \times \mathrm{CH}_{2}\right), 3.67(\mathrm{t}, 2 \mathrm{H}, J$ $\left.=4.8 \mathrm{~Hz}, \mathrm{CH}_{2}\right), 3.78-3.92\left(\mathrm{~m}, 3 \mathrm{H}, \mathrm{CH}_{2}, \mathrm{CH}\right), 7.39(\mathrm{~d}, 1 \mathrm{H}, J=7.4 \mathrm{~Hz}, \mathrm{Ar}-\mathrm{H}), 7.70-7.83(\mathrm{~m}$, $2 \mathrm{H}, 2 \times \mathrm{Ar}-\mathrm{H}), 7.98(\mathrm{dd}, 1 \mathrm{H}, J=1.7,8.5 \mathrm{~Hz}, \mathrm{Ar}-\mathrm{H}), 8.57(\mathrm{~s}, 2 \mathrm{H}, 2 \times \mathrm{Ar}-\mathrm{H}), 8.70(\mathrm{t}, 1 \mathrm{H}, J=$ $4.9 \mathrm{~Hz}, \mathrm{ArCONH}), 10.73$ (s, 1H, $\left.\mathrm{NH}^{+}\right), 11.68$ (s, 1H, pyrr-NH/pyrr-CONH), 12.23 (s, 1H, pyrr-NH/pyrr-CONH), $14.91(\mathrm{~s}, 1 \mathrm{H}, \mathrm{COOH})$. IR (ATR) $v\left[\mathrm{~cm}^{-1}\right]=3365(\mathrm{NH}), 3223(\mathrm{NH})$, 2925 (OH), 1719 (CO), 1657 (CO), 1627 (CO), 1525, 1455, 1400, 1331, 1264, 1167, 1104, 1036, $944,913,892,833,748,702,621,551,519$. HRMS $\left(\mathrm{ESI}^{+}\right) \mathrm{m} / z$ for $\mathrm{C}_{35} \mathrm{H}_{35} \mathrm{Cl}_{2} \mathrm{FN}_{7} \mathrm{O}_{6} \mathrm{~S}([\mathrm{M}+$ $\left.\mathrm{H}^{+}\right)$: calculated: 770.1725 , found: 770.1725 , delta: -0.03 ppm. HPLC: $t_{\mathrm{r}} 4.82 \mathrm{~min}(95.1 \%$ at $254 \mathrm{~nm})$.

1-(2-(2-(4-(Benzyloxy)-2-(3,4-dichloro-5-methyl-1H-pyrrole-2-carboxamido) benzo[ $d]$ thiazole-6-carboxamido)ethoxy)ethyl)-4-(3-carboxy-1-cyclopropyl-6-fluoro-4 -oxo-1,4-dihydroquinolin-7-yl)piperazin-1-ium chloride (11b). Synthesized according to General procedure A with $1 \mathrm{~b}(40 \mathrm{mg}, 0.084 \mathrm{mmol})$ and $10(41 \mathrm{mg}, 0.084 \mathrm{mmol})$ as reactants. After isolation, the product was additionally purified by washing with hot water three times and by crystallization from methanol. Yield: $3.42 \mathrm{mg}(4.5 \%)$; light beige solid; $\mathrm{mp}>$ $300{ }^{\circ} \mathrm{C} .{ }^{1} \mathrm{H}$ NMR $\left(400 \mathrm{MHz}, \mathrm{DMSO}-d_{6}\right) \delta[\mathrm{ppm}] 1.13-1.22\left(\mathrm{~m}, 4 \mathrm{H}, 2 \times\right.$ cyclopropyl- $\left.\mathrm{CH}_{2}\right)$, 
$2.25\left(\mathrm{~s}, 3 \mathrm{H}\right.$, pyrr- $\left.\mathrm{CH}_{3}\right), 3.03\left(\mathrm{t}, 2 \mathrm{H}, \mathrm{J}=12.1 \mathrm{~Hz}, \mathrm{CH}_{2}\right), 3.24-3.29\left(\mathrm{~m}, 2 \mathrm{H}, \mathrm{CH}_{2}\right), 3.39-3.48(\mathrm{~m}$, $\left.4 \mathrm{H}, 2 \times \mathrm{CH}_{2}\right), 3.52-3.61\left(\mathrm{~m}, 4 \mathrm{H}, 2 \times \mathrm{CH}_{2}\right), 3.63-3.70\left(\mathrm{~m}, 2 \mathrm{H}, \mathrm{CH}_{2}\right), 3.74-3.79(\mathrm{~m}, 1 \mathrm{H}, \mathrm{CH})$, $3.84\left(\mathrm{~s}, 2 \mathrm{H}, \mathrm{CH}_{2}\right), 5.29$ (s, 2H, Bn-CH$), 7.26$ (d, 1H, J = 7.2 Hz, Ar-H), 7.35-7.47 (m, 3H, 3 $\times \mathrm{Ar}-\mathrm{H}), 7.48-7.55(\mathrm{~m}, 2 \mathrm{H}, 2 \times \mathrm{Ar}-\mathrm{H}), 7.64(\mathrm{~d}, J=1.5 \mathrm{~Hz}, \mathrm{Ar}-\mathrm{H}), 7.75(\mathrm{~d}, 1 \mathrm{H}, J=12.9 \mathrm{~Hz}$, Ar-H), 8.12 (s, 1H, Ar-H), 8.54 (s, 1H, Ar-H), 8.64 (s, 1H, ArCONH), $10.12\left(\mathrm{~s}, 1 \mathrm{H}, \mathrm{NH}^{+}\right)$, 11.80 (s, 1H, pyrr-NH/pyrr-CONH), 11.92 (s, 1H, pyrr-NH/pyrr-CONH), 14.87 (s, 1H, $\mathrm{COOH})$. HRMS $\left(\mathrm{ESI}^{+}\right) \mathrm{m} / z$ for $\mathrm{C}_{42} \mathrm{H}_{41} \mathrm{Cl}_{2} \mathrm{FN}_{7} \mathrm{O}_{7} \mathrm{~S}\left([\mathrm{M}+\mathrm{H}]^{+}\right)$: calculated: 876.2144 , found: 876.2135, delta: -1.00 ppm. HPLC: $t_{\mathrm{r}} 5.54 \mathrm{~min}(93.1 \%$ at $254 \mathrm{~nm})$.

\section{References}

1. Silver, L.L. Multi-targeting by monotherapeutic antibacterials. Nat. Rev. Drug Discov. 2007, 6, 41-55. [CrossRef]

2. Mayer, C.; Janin, Y.L. Non-quinolone inhibitors of bacterial type IIA topoisomerases: A feat of bioisosterism. Chem. Rev. 2014, 114, 2313-2342. [CrossRef]

3. Tomašić, T.; Mašič, L.P. Prospects for developing new antibacterials targeting bacterial type IIA topoisomerases. Curr. Top. Med. Chem. 2014, 14, 130-151. [CrossRef] [PubMed]

4. Champoux, J.J. DNA Topoisomerases: Structure, function, and mechanism. Ann. Rev. Biochem. 2001, 70, 369-413. [CrossRef] [PubMed]

5. Hooper, D.C.; Jacoby, G.A. Topoisomerase inhibitors: Fluoroquinolone mechanisms of action and resistance. Cold Spring Harb. Perspect. Med. 2016, 6. [CrossRef] [PubMed]

6. Pham, T.D.M.; Ziora, Z.M.; Blaskovich, M.A.T. Quinolone antibiotics. Med. Chem. Commun. 2019, 10, 1719-1739. [CrossRef] [PubMed]

7. Bisacchi, G.S.; Manchester, J.I. A new-class antibacterial-Almost. Lessons in drug discovery and development: A critical analysis of more than 50 years of effort toward ATPase Inhibitors of DNA gyrase and topoisomerase IV. ACS Infect. Dis. 2015, 1, 4-41. [CrossRef]

8. Gross, C.H.; Parsons, J.D.; Grossman, T.H.; Charifson, P.S.; Bellon, S.; Jernee, J.; Dwyer, M.; Chambers, S.P.; Markland, W.; Botfield, M.; et al. Active-site residues of Escherichia coli DNA gyrase required in coupling ATP hydrolysis to DNA supercoiling and amino acid substitutions leading to novobiocin resistance. Antimicrob. Agents Chemother. 2003, 47, 1037-1046. [CrossRef]

9. Redgrave, L.S.; Sutton, S.B.; Webber, M.A.; Piddock, L.J.V. Fluoroquinolone resistance: Mechanisms, impact on bacteria, and role in evolutionary success. Trends Microbiol. 2014, 22, 438-445. [CrossRef]

10. Fluoroquinolone and Quinolone Antibiotics: PRAC Recommends Restrictions on Use. Available online: https://www.ema. europa.eu/en/documents/press-release/fluoroquinolone-quinolone-antibiotics-prac-recommends-restrictions-use_en.pdf (accessed on 5 October 2019).

11. Kim, E.S.; Hooper, D.C. Clinical importance and epidemiology of quinolone resistance. Infect. Chemother. 2014, 46, 226-238. [CrossRef]

12. Aldred, K.J.; Kerns, R.J.; Osheroff, N. Mechanism of quinolone action and resistance. Biochem. 2014, 53, 1565-1574. [CrossRef] [PubMed]

13. Correia, S.; Poeta, P.; Hébraud, M.; Capelo, J.L.; Igrejas, G. Mechanisms of quinolone action and resistance: Where do we stand? J. Med. Microbiol. 2017, 66, 551-559. [CrossRef] [PubMed]

14. Collin, F.; Karkare, S.; Maxwell, A. Exploiting bacterial DNA gyrase as a drug target: Current state and perspectives. Appl. Microbiol. Biotechnol. 2011, 92, 479-497. [CrossRef] [PubMed]

15. Tomašič, T.; Katsamakas, S.; Hodnik, Ž.; Ilaš, J.; Brvar, M.; Solmajer, T.; Montalvão, S.; Tammela, P.; Banjanac, M.; Ergović, G.; et al. Discovery of 4,5,6,7-Tetrahydrobenzo[1,2- $d$ ] thiazoles as Novel DNA gyrase inhibitors targeting the ATP-binding site. J. Med. Chem. 2015, 58, 5501-5521. [CrossRef]

16. Zidar, N.; Macut, H.; Tomašič, T.; Brvar, M.; Montalvão, S.; Tammela, P.; Solmajer, T.; Peterlin Mašič, L.; Ilaš, J.; Kikelj, D. N -Phenyl-4,5-dibromopyrrolamides and $N$-Phenylindolamides as ATP competitive DNA gyrase B inhibitors: Design, synthesis, and evaluation. J. Med. Chem. 2015, 58, 6179-6194. [CrossRef]

17. Gjorgjieva, M.; Tomašič, T.; Barančokova, M.; Katsamakas, S.; Ilaš, J.; Tammela, P.; Peterlin Mašič, L.; Kikelj, D. Discovery of benzothiazole scaffold-based DNA gyrase B inhibitors. J. Med. Chem. 2016, 59, 8941-8954. [CrossRef]

18. Durcik, M.; Lovison, D.; Skok, Ž.; Durante Cruz, C.; Tammela, P.; Tomašič, T.; Benedetto Tiz, D.; Draskovits, G.; Nyerges, Á.; Pál, C.; et al. New N-phenylpyrrolamide DNA gyrase B inhibitors: Optimization of efficacy and antibacterial activity. Eur. J. Med. Chem. 2018, 154, 117-132. [CrossRef]

19. Tomašič, T.; Barančoková, M.; Zidar, N.; Ilaš, J.; Tammela, P.; Kikelj, D. Design, synthesis, and biological evaluation of 1-ethyl-3(thiazol-2-yl)urea derivatives as Escherichia coli DNA gyrase inhibitors. Arch. Pharm. 2018, 351, 1700333. [CrossRef]

20. Fois, B.; Skok, Ž.; Tomašič, T.; Ilaš, J.; Zidar, N.; Zega, A.; Peterlin Mašič, L.; Szili, P.; Draskovits, G.; Nyerges, Á. Dual Escherichia coli DNA Gyrase A and B Inhibitors with Antibacterial Activity. Chem. Med. Chem. 2020, 15, 265-269. [CrossRef]

21. Nyerges, A.; Tomašič, T.; Durcik, M.; Revesz, T.; Szili, P.; Draskovits, G.; Bogar, F.; Skok, Ž.; Zidar, N.; Ilaš, J. Rational design of balanced dual-targeting antibiotics with limited resistance. PLoS Biol. 2020, 18, e3000819. [CrossRef] 
22. Rice, L.B. Federal funding for the study of antimicrobial resistance in nosocomial pathogens: No ESKAPE. J. Infect. Dis. 2008, 197, 1079-1081. [CrossRef] [PubMed]

23. Vanden Broeck, A.; Lotz, C.; Ortiz, J.; Lamour, V. Cryo-EM structure of the complete E. coli DNA gyrase nucleoprotein complex. Nat. Commun. 2019, 10, 4935. [CrossRef] [PubMed]

24. Chan, P.F.; Srikannathasan, V.; Huang, J.; Cui, H.; Fosberry, A.P.; Gu, M.; Hann, M.M.; Hibbs, M.; Homes, P.; Ingraham, K.; et al. Structural basis of DNA gyrase inhibition by antibacterial QPT-1, anticancer drug etoposide and moxifloxacin. Nat. Commun. 2015, 6, 10048. [CrossRef]

25. The PyMOL Molecular Graphics System, Version 1.8; Schrödinger, LLC.: New York, NY, USA, 2014.

26. Durcik, M.; Tammela, P.; Barančoková, M.; Tomašič, T.; Ilaš, J.; Kikelj, D.; Zidar, N. Synthesis and Evaluation of N-Phenylpyrrolamides as DNA Gyrase B Inhibitors. Chem. Med. Chem. 2018, 13, 186-198. [CrossRef] [PubMed]

27. Nyerges, Á.; Csörgő, B.; Nagy, I.; Bálint, B.; Bihari, P.; Lázár, V.; Apjok, G.; Umenhoffer, K.; Bogos, B.; Pósfai, G. A highly precise and portable genome engineering method allows comparison of mutational effects across bacterial species. Proc. Natl. Acad. Sci. USA 2016, 113, 2502-2507. [CrossRef] [PubMed]

28. Szili, P.; Draskovits, G.; Révész, T.; Bogár, F.; Balogh, D.; Martinek, T.; Daruka, L.; Spohn, R.; Vásárhelyi, B.M.; Czikkely, M.; et al. Rapid evolution of reduced susceptibility against a balanced dual-targeting antibiotic through stepping-stone mutations. Antimicrob. Agents Chemother. 2019, 63. [CrossRef]

29. Baba, T.; Ara, T.; Hasegawa, M.; Takai, Y.; Okumura, Y.; Baba, M.; Datsenko, K.A.; Tomita, M.; Wanner, B.L.; Mori, H. Construction of Escherichia coli K-12 in-frame, single-gene knockout mutants: The Keio collection. Mol. Syst. Biol. 2006, 2, 2006.0008. [CrossRef]

30. CLSI. Methods for Antimicrobial Susceptibility Testing of Anaerobic Bacteria; Approved Standard-Eighth Edition. CLSI document M11-A8; Clinical and Laboratory Standards Institute: Wayne, PA, USA, 2012.

31. Baker, K.R.; Sigurðardóttir, H.H.; Jana, B.; Guardabassi, L. Cephem potentiation by inactivation of nonessential genes involved in cell wall biogenesis of $\beta$-lactamase-producing Escherichia coli. Antimicrob. Agents Chemother. 2017, 61. [CrossRef]

32. Pourahmad Jaktaji, R.; Jazayeri, N. Expression of $\operatorname{acr} A$ and $\operatorname{acrB}$ Genes in Esherichia coli Mutants with or without marR or acrR Mutations. Iran. J. Basic Med. Sci. 2013, 16, 1254-1258. 